Tetrahedron

journal homepage: www.elsevier.com

\title{
Copper-Catalyzed Enantioselective Allylic Cross-Coupling with Alkylboranes
}

\author{
Kentaro Hojoh ${ }^{\mathrm{a}}$, Yoshinori Shido ${ }^{\mathrm{a}}$, Kazunori Nagao ${ }^{\mathrm{a}}$, Seiji Mori ${ }^{\mathrm{b}}$, Hirohisa Ohmiya ${ }^{\mathrm{a}} *$ and Masaya \\ Sawamura $^{\mathrm{a} *}$ \\ ${ }^{a}$ Department of Chemistry, Faculty of Science, Hokkaido University, Sapporo 060-0810, Japan \\ ${ }^{b}$ Faculty of Science, Ibaraki University, Mito 310-8512, Japan
}

\section{ARTICLE INFO \\ ABSTRACT}

Article history:

Received

Received in revised form

Accepted

Available online

Keywords:

asymmetric catalysis

copper catalyst

allylic substitution

alkylborane

quaternary carbon
Type your Abstract text here

2009 Elsevier Ltd. All rights reserved.

We have presented full details of our work on alkylboranes, which we have introduced as new reagents for copper-catalyzed $\mathrm{S}_{\mathrm{N}} 2$ '-type enantioselective allylic substitutions. The copper catalysis delivered enantioenriched chiral products containing tertiary or quaternary carbon stereogenic centers branched with functionalized $\mathrm{sp}^{3}$-alkyl groups. The wide availability of alkylboranes via the established alkene hydroboration reaction is an attractive feature of these transformations. Various functional groups are tolerated in the substrates. A reaction pathway involving addition-elimination of a neutral alkylcopper(I) species with the allyl chloride substrate is proposed.

\section{Introduction}

Enantioselective allylic substitutions of organometallic reagents under the influence of chiral transition metal catalysts are efficient and versatile methods for asymmetric carbon-carbon bond formation. ${ }^{1}$ In recent decades, reactions using organoboron compounds as organometallic reagents for allylic substitutions have achieved remarkable advances, given their broad substrate scopes and functional group compatibilities. ${ }^{2-6}$ Unfortunately, however, usable organoboron reagents have generally been limited to aryl-, alkenyl-, allyl- and allenylboron compounds, and the reactions of alkylboron derivatives have been rare and underdeveloped until very recently. ${ }^{\text {a }}$ In 2012 , we reported the first catalytic enantioselective allylic substitution reaction with alkylboron compounds under catalysis of a chiral $\mathrm{Cu}(\mathrm{I})$ complex system. Later, the system was extended to catalytic enantioselective construction of all-carbon quaternary stereogenic centers. ${ }^{7 \mathrm{~b}}$ Herein, we present full details of our studies on the use of alkylboranes for copper-catalyzed $\mathrm{S}_{\mathrm{N}} 2$ '-type enantioselective allylic substitutions. ${ }^{8,9}$

\section{Results/Discussion}

2.1. Construction of tertiary carbon stereogenic centers using $\gamma$-monosubstituted primary allylic substrates.
2.1.1. Optimization. Previously, we reported that the allyl-alkyl coupling between enantioenriched chiral secondary (Z)-allylic phosphates and alkyl-9-BBN reagents proceeded with excellent $\gamma$-selectivity and stereospecificity under the influence of a catalytic amount of a copper(I) salt and a stoichiometric potassium alkoxide base (Scheme 1). ${ }^{8 \mathrm{a}-\mathrm{c}}$ On the basis of this knowledge, we initiated a program to develop an unprecedented catalytic enantioselective allylic alkylation with alkylboranes. Initial screening of ligands was conducted for the reaction of alkylborane 2a $(0.25 \mathrm{mmol})$, which was prepared from dimethoxyallylbenzene (1a), and $\gamma$-monosubstituted primary allyl chloride $(Z)$-3a $(0.2 \mathrm{mmol})$ in the presence of $\mathrm{CuCl}(5 \mathrm{~mol} \%)$ and $\mathrm{MeOK}$ in 1,4 -dioxane at $35{ }^{\circ} \mathrm{C}$ (Table 1). ${ }^{10}$ The ringunsaturated $C_{2}$-symmetric $N$-heterocyclic carbene ligand $(\mathbf{L 1})^{11}$ having 1-(1-naphthyl)ethyl groups at both nitrogen atoms gave racemic 4aa (entry 1). The chiral phosphoramidite ligand (L2) did not form an active catalyst (entry 2). Further screening of various chiral ligands revealed that introducing 3,5-di-t-butyl-4methoxyphenyl (DTBM) substituents on the phosphorus atoms of chiral bisphosphines was essential not only for enantiocontrol, but also for catalytic activity with bisphosphine-based chiral copper catalysts. $(R)$-DTBM-BINAP (L3) induced low catalytic activity and enantioselectivity (entry 3 ). The use of DTBM-MeOBIPHEP (L4) gave better product yield and enantioselectivity (entry 4). The use of $(R)$-DTBM-SEGPHOS ${ }^{12}$ (L5) led to an improvement in the product yield and enantioselectivity (entry $5)$, giving the branched $\gamma$-substitution product $(S)-4$ aa $(\gamma / \alpha>$

* Hirohisa Ohmiya. Tel.: +81-11-706-2719; fax: +81-11-706-3749; e-mail: ohmiya@sci.hokudai.ac.jp

* Masaya Sawamura. Tel.: +81-11-706-3434; fax: +81-11-706-3749; e-mail: sawamura@sci.hokudai.ac.jp 
20:1). In contrast, non-DTBM-substituted chiral bisphosphines, $(R)$-SEGPHOS $(\mathbf{L 6})$ or $(R, R)$-Quinox $\mathrm{P}^{*}(\mathbf{L 7}),{ }^{13}$ resulted in complete inhibition of the reaction or loss of enantiocontrol, respectively (entries 6 and 7). The introduction of the DTBM substituents may have induced the deaggregation of alkylcopper(I) species to form a catalytically active monomeric copper complex. ${ }^{14}$

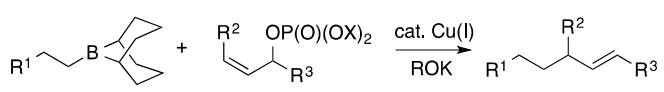

Scheme 1. Copper-catalyzed cross-coupling between alkylboranes and secondary $(Z)$-allylic phosphates.

Next, the effect of solvent was examined in the reaction between 2a and (Z)-3a with the CuCl-L5 catalyst system (Table 1 , entries $8-12$ ). The use of THF or toluene as a solvent instead of 1,4-dioxane resulted in poor yields $(11 \%$ and $7 \%)$ and lower enantioselectivities ( $40 \%$ and $41 \%$ ees) (entries 8 and 9). Dichloromethane (DCM) as solvent inhibited the reaction almost completely (entry 10). The enantioselection was improved to $74 \%$ ee by carrying out the reaction at $10{ }^{\circ} \mathrm{C}$ with $10 \mathrm{~mol} \%$ catalyst loading in 1,4-dioxane, but with a serious reduction of the yield $(23 \%$, entry 11$)$. Finally, we found that the reaction proceeded much more efficiently in a mixed solvent system, 1,4dioxane/DCM (1:3). The reaction with $10 \mathrm{~mol} \%$ catalyst loading at $10{ }^{\circ} \mathrm{C}$ afforded $(S)-4 a a$ with $77 \%$ ee in $81 \%$ yield (entry 12 ). A slightly higher yield $(83 \%)$ was obtained by changing $\mathrm{CuCl}$ to CuOTf (toluene) 0.5 with the enantioselectivity unchanged (entry 13). The enantioselection could be improved to $80 \%$ ee by reducing the reaction temperature to $5{ }^{\circ} \mathrm{C}$ at the expense of the yield (55\%) (entry 14$)$.

Table 1. Copper-catalyzed enantioselective allylic substitutions between alkylborane $\mathbf{2 a}$ and $(Z)$-3a under various conditions. ${ }^{a}$
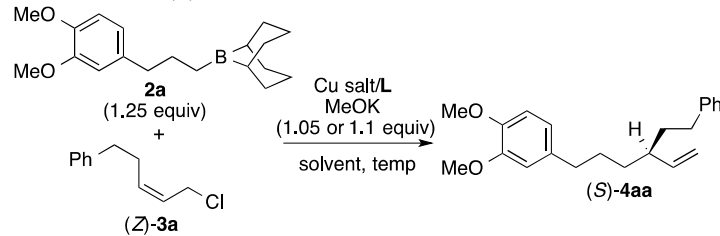

\begin{tabular}{llllllcc}
\hline entry & $\begin{array}{l}\mathrm{Cu} / \mathrm{L} \\
(\mathrm{mol} \%)\end{array}$ & $\mathrm{Cu}$ salt & $\mathbf{L}$ & solvent & $\begin{array}{l}\text { temp } \\
\left({ }^{\circ} \mathrm{C}\right)\end{array}$ & $\begin{array}{l}\text { yield } \\
(\%)^{b, c}\end{array}$ & $\begin{array}{l}\text { ee } \\
(\%)^{d}\end{array}$ \\
\hline 1 & 5 & $\mathrm{CuCl}$ & $\mathbf{L 1}$ & dioxane & 35 & 3 & 0 \\
2 & 5 & $\mathrm{CuCl}$ & $\mathbf{L 2}$ & dioxane & 35 & 0 & - \\
3 & 5 & $\mathrm{CuCl}$ & $\mathbf{L 3}$ & dioxane & 35 & 5 & 37 \\
4 & 5 & $\mathrm{CuCl}$ & $\mathbf{L 4}$ & dioxane & 35 & 25 & 47 \\
5 & 5 & $\mathrm{CuCl}$ & $\mathbf{L 5}$ & dioxane & 35 & 48 & 61 \\
6 & 5 & $\mathrm{CuCl}$ & $\mathbf{L 6}$ & dioxane & 35 & 0 & - \\
7 & 5 & $\mathrm{CuCl}$ & $\mathbf{L 7}$ & dioxane & 35 & 99 & 7 \\
8 & 5 & $\mathrm{CuCl}$ & $\mathbf{L 5}$ & THF & 35 & 11 & 40 \\
9 & 5 & $\mathrm{CuCl}$ & $\mathbf{L 5}$ & toluene & 35 & 7 & 41 \\
10 & 5 & $\mathrm{CuCl}$ & $\mathbf{L 5}$ & DCM & 35 & trace & - \\
11 & 10 & $\mathrm{CuCl}$ & $\mathbf{L 5}$ & dioxane & 10 & 23 & 74 \\
12 & 10 & $\mathrm{CuCl}$ & $\mathbf{L 5}$ & dioxane/DCM & 10 & 81 & 77 \\
13 & 10 & $\mathrm{CuOTf} \cdot($ toluene) 0.5 & $\mathbf{L 5}$ & dioxane/DCM & 10 & 83 & 77 \\
14 & 10 & $\mathrm{CuOTf}$ (toluene) 0.5 & $\mathbf{L 5}$ & dioxane/DCM & 5 & 55 & 80 \\
\hline
\end{tabular}

${ }^{a}$ The reaction was carried out with $(Z)-3 a(0.2 \mathrm{mmol}), 2 \mathbf{2 a}(0.25 \mathrm{mmol}), \mathrm{Cu}$ salt, ligand (L), and $\mathrm{MeOK}(0.21 \mathrm{mmol}$, entries $1-10$; $0.22 \mathrm{mmol}$, entries 11$14)$ in solvent $(0.8 \mathrm{~mL})$ for $12 \mathrm{~h}$ (entries $1-10)$ or $48 \mathrm{~h}$ (entries 11-14). Alkylborane 2 was prepared in advance by hydroboration of 1 with the 9BBN dimer at $60{ }^{\circ} \mathrm{C}(1 \mathrm{~h})$ and used without purification. ${ }^{b}$ The yield was determined by ${ }^{1} \mathrm{H}$ NMR. ${ }^{c}$ Constitutional isomer ratio $\gamma / \alpha>20: 1$ (determined by ${ }^{1} \mathrm{H}$ NMR analysis of the crude product). ${ }^{d}$ The enantiomeric excess was determined by HPLC analysis.
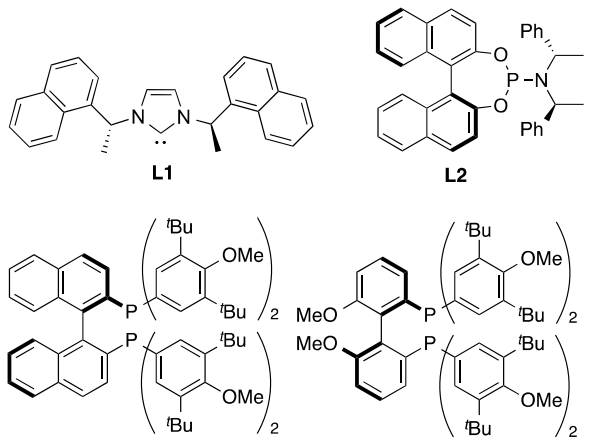

(R)-DTBM-BINAP (L3)

(R)-DTBM-MeO-BIPHEP (L4)
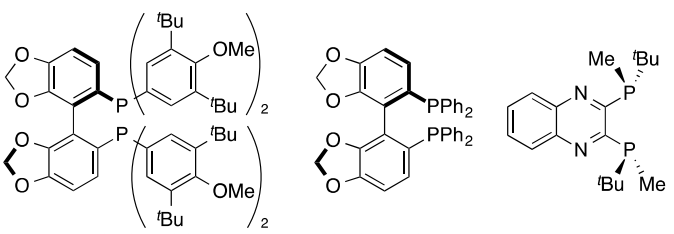

(R)-DTBM-SEGPHOS (L5)

$(R)$-SEGPHOS (L6) $\quad(R, R)$-QuinoxP* $(\mathbf{L 7})$

2.1.2. Effects of leaving groups and bases. Effects of leaving groups and bases were examined in the reaction of $\mathbf{2 a}$ and $(\mathrm{Z})-\mathbf{3 a}$ under the conditions for Table 1 , entry $5[\mathrm{CuCl} / \mathbf{L} 5,1,4$-dioxane, $35{ }^{\circ} \mathrm{C}$ ] (Table 2).${ }^{10}$ Replacing the leaving group with a bromide or phosphate caused drastic reductions of the product yield and enantioselectivity (entries 1-3).

Changing the alkoxide base from $\mathrm{MeOK}$ to the bulkier $t$ BuOK decreased the yield (39\%) and enantioselectivity (57\% ee) (Table 2, entry 4). No reaction occurred with the weaker base PhOK (entry 5). The use of $\mathrm{Li}$ or $\mathrm{Na}$ methoxides also resulted in virtually no reaction (entries 6 and 7).

The inefficiency of the $\mathrm{Li}$ or $\mathrm{Na}$ methoxides may reflect higher solubilities of Li or Na salts, which may cause inhibitory effects in the hydrophobic solution phase of the reaction mixture. This assumption also explains the increase in the reaction efficiency when DCM was used as a co-solvent with 1,4-dioxane (Table 1 , entry 12).

Table 2. Effect of leaving groups and bases.

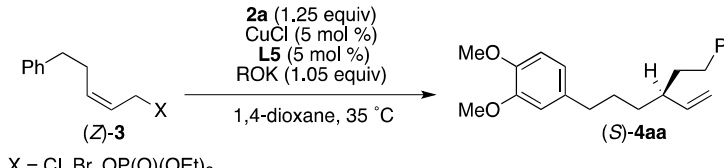

\begin{tabular}{lllll}
\multicolumn{2}{c}{$\mathrm{X}=\mathrm{Cl}, \mathrm{Br}, \mathrm{OP}(\mathrm{O})(\mathrm{OEt})_{2}$} & $\mathrm{ROK}$ & $\begin{array}{l}\text { yield } \\
(\%)^{b, c}\end{array}$ & $\begin{array}{l}\text { ee } \\
(\%)^{d}\end{array}$ \\
\hline entry & leaving group & $\mathrm{MeOK}$ & 48 & 61 \\
\hline 1 & $\mathrm{Cl}($ Table 1, entry 5) & $\mathrm{MeOK}$ & 18 & 34 \\
2 & $\mathrm{Br}$ & $\mathrm{MeOK}$ & 5 & 13 \\
3 & $\mathrm{OP}(\mathrm{O})(\mathrm{OEt})_{2}$ & $t$ - & 39 & 57 \\
4 & $\mathrm{Cl}$ & $\mathrm{PhOK}$ & 0 & - \\
5 & $\mathrm{Cl}$ & $\mathrm{MeOLi}$ & trace & - \\
6 & $\mathrm{Cl}$ & $\mathrm{MeONa}$ & 0 & - \\
7 & $\mathrm{Cl}$ & 0 & \\
\hline
\end{tabular}

${ }^{a}$ The reaction was carried out with $3(0.2 \mathrm{mmol}), 2 \mathrm{a}(0.25 \mathrm{mmol}), \mathrm{Cu}$ salt $(5$ mol\%), L5 (5 mol\%), and base $(0.21 \mathrm{mmol})$ in 1,4-dioxane $(0.8 \mathrm{~mL})$ for $12 \mathrm{~h}$. Alkylborane 2 was prepared in advance by hydroboration of 1 with the 9BBN dimer at $60{ }^{\circ} \mathrm{C}(1 \mathrm{~h})$ and used without purification. ${ }^{b}$ The yield was determined by ${ }^{1} \mathrm{H}$ NMR. ${ }^{c}$ Constitutional isomer ratio $\gamma / \alpha>20: 1$ (determined by ${ }^{1} \mathrm{H}$ NMR analysis of the crude product). ${ }^{d}$ The enantiomeric excess was determined by HPLC analysis. 
2.1.3 Effect of alkene geometry. The reaction of allyl chloride 3a with $E$-configuration under the optimized conditions (the conditions for Table 1, entry 13) provided the product with the same absolute configuration with $64 \%$ ee (see section 2.5 for discussion on the effect of alkene geometries). ${ }^{10,15}$

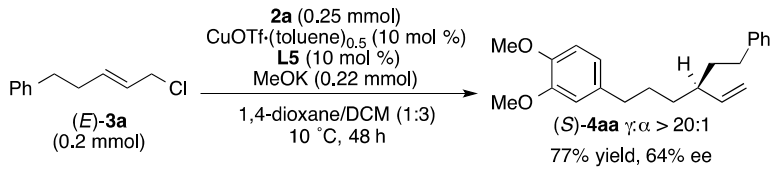

Scheme 2. Copper-catalyzed allylic substitutions of alkylborane and (E)-allyl chloride.

2.1.4. Substrate scopes. Various terminal alkenes (1) and $Z$-allyl chlorides (3) were subjected to 9-BBN-hydroboration and were used for the enantioselective allylic substitution with the CuOTf·(toluene $)_{0.5} /(R)$-DTBM-SEGPHOS (L5) catalyst system (Table 3). ${ }^{10}$ The reactions proceeded with excellent $\gamma$-selectivities $(\gamma / \alpha>20: 1)$ and high enantioselectivities (76-90\% ee). Terminal alkenes having functional groups such as acetal, silyl ether, ester and phthalimide moieties at the terminal of the aliphatic chain were compatible with the protocol (entries 1-8). Functional groups such as chloro and silyl ether moieties in the allylic substrates were also tolerated (entries 2, 7 and 8).

The tolerance of this reaction toward smaller or sterically more demanding $\gamma$-substituents is demonstrated in the successful conversion of the $\gamma$-methyl or $\gamma$-cyclohexyl-substituted allyl chlorides (3d, e), although reductions in yield and enantioselection were observed (4dd, 70\%, $81 \%$ ee; 4de, 53\%, $76 \%$ ee, Table 3, entries 4 and 5). Unfortunately, the attempt to use the alkylborane (2g) derived from styrene (1g) failed (entry 9).

Table 3. Scope of enantioselective allylic substitution with alkylboranes. ${ }^{a}$ $\mathrm{R}^{1} \widehat{1}$

$$
\text { entry }
$$

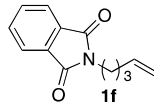

\section{$8 \quad \mathbf{1 f}$}

(Z)-3c

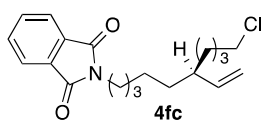

$9 \mathrm{Ph} \widehat{\mathrm{N}}$

(Z)-3a

${ }^{a}$ The reaction was carried out with $(Z)-3(0.2 \mathrm{mmol}), 2(0.25 \mathrm{mmol})$, CuOTf (toluene) $)_{0.5}(10 \mathrm{~mol} \%)$, L5 (10 mol \%), and MeOK $(0.22 \mathrm{mmol})$ in 1,4-dioxane/DCM $(1: 3,0.8 \mathrm{~mL})$ at $10{ }^{\circ} \mathrm{C}($ entry 3$)$ or $15{ }^{\circ} \mathrm{C}$ (entries 1,2 and 4-9) for $48 \mathrm{~h}$ (entries 2, 3, 7 and 9) or $72 \mathrm{~h}$ (entries 1, 4-6 and 8). Alkylborane 2 was prepared in advance by hydroboration of 1 with the 9BBN dimer at $60{ }^{\circ} \mathrm{C}(1 \mathrm{~h})$ and used without purification. ${ }^{b} \mathrm{The}$ yield of the isolated product. ${ }^{c}$ Constitutional isomer ratio $\gamma / \alpha>20: 1$ (determined by ${ }^{1} \mathrm{H}$ NMR analysis of the crude product). ${ }^{d}$ The enantiomeric excess was determined by HPLC analysis. ${ }^{e}$ Reaction on $1.0 \mathrm{mmol}$ scale. ${ }^{2} \mathbf{2}(0.34 \mathrm{mmol})$ and $\mathrm{MeOK}(0.3 \mathrm{mmol})$ were used.

2.1.5. Synthesis of chiral allylsilanes. The reaction between a $\gamma$ silylated allyl chloride (3g) and alkylboranes afforded enantioenriched $\alpha$-stereogenic chiral allylsilanes (Table 4). ${ }^{10,16-18}$ For instance, the reaction between alkylborane $\mathbf{2 h}$, which was derived from terminal alkene $\mathbf{1 h}$, and $\mathbf{3 g}$ under the conditions optimized for the reaction of $(Z)$-3a proceeded with complete $\gamma$ selectivity, and afforded chiral allylsilane $\mathbf{4 h g}$ with $91 \%$ ee in $77 \%$ yield (entry 1). The terminal alkenes (1c,e,f,i) bearing acetal, ester, phthalimide or chloro moieties were also compatible with the protocol with comparable enantioselectivities (entries 2 $5)$.

Table 4. Synthesis of chiral allylsilanes. ${ }^{a}$

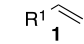

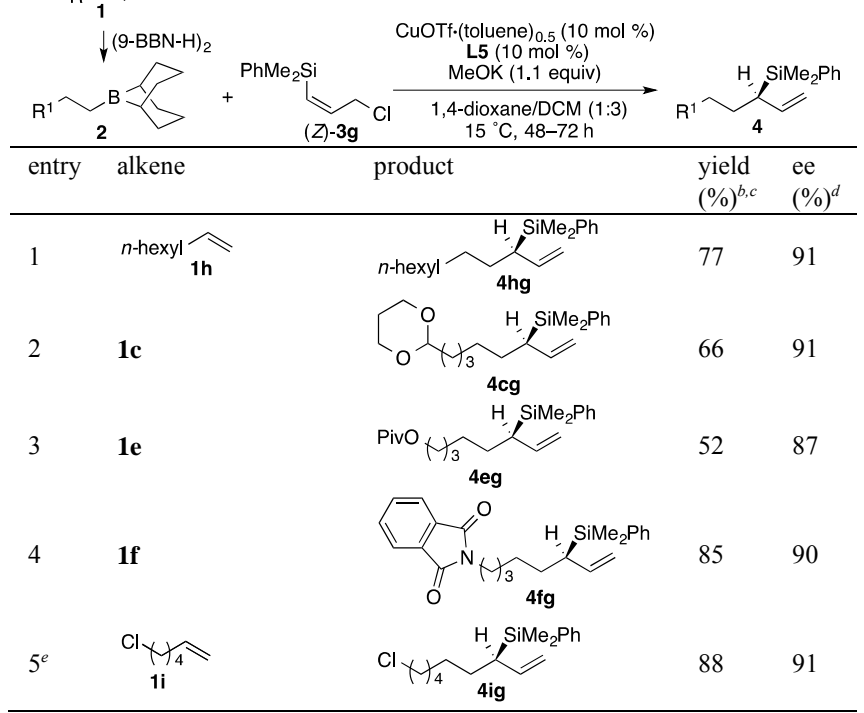

${ }^{a}$ The reaction was carried out with $(Z)-3 g(0.2 \mathrm{mmol}), 2(0.25 \mathrm{mmol})$, CuOTf (toluene) $)_{0.5}(10 \mathrm{~mol} \%)$, L5 (10 mol \%), and $\mathrm{MeOK}(0.22 \mathrm{mmol})$ in 1,4-dioxane/DCM $(1: 3,0.8 \mathrm{~mL})$ at $15{ }^{\circ} \mathrm{C}$ for $48 \mathrm{~h}$ (entries $1,2,4$ and 5$)$ or 72 h (entry 3). Alkylborane 2 was prepared in advance by hydroboration of 1 with the 9-BBN dimer at $60{ }^{\circ} \mathrm{C}(1 \mathrm{~h})$ and used without purification. ${ }^{b}$ The yield of the isolated product. ${ }^{~}$ Linear isomer was not detected: $\gamma / \alpha>99: 1\left({ }^{1} \mathrm{H}\right.$ NMR). ${ }^{d}$ The enantiomeric excess was determined by HPLC analysis. ${ }^{e}$ Reaction on $1.0 \mathrm{mmol}$ scale.

\subsection{Construction of quaternary carbon stereogenic centers using $\gamma, \gamma$-disubstituted primary allylic substrates.}

2.2.1. Background on construction of quaternary carbon stereogenic centers. Catalytic enantioselective construction of all-carbon quaternary stereogenic centers in acyclic systems is one of the biggest challenges in organic synthesis. ${ }^{19}$ One of the 
obstacles is low reactivity due to the steric repulsion that occurs in the carbon-carbon bond formation step. It is also difficult to discriminate the enantiotopic faces due to steric congestion and the diminished steric difference between the non-hydrogen substituents. To this end, transition-metal-catalyzed enantioselective allylic substitutions with organometallic nucleophiles such as organolithium, Grignard, diorganozinc or triorganoaluminum reagents have proven to be effective strategies. ${ }^{1}$ Organoboron compounds have also been used for enantioselective construction of all-carbon quaternary stereogenic centers through allylic substitution. ${ }^{4,5 b}$ However, the methodology has not yet been generalized to allow the reaction of $s p^{3}$-alkylboron nucleophiles.

The aforementioned enantioselective copper-catalyzed reaction was not applicable to the construction of quaternary stereogenic centers (section 2.1). However, only a slight modification to the catalyst system enabled the construction of a quaternary stereogenic carbon center through copper-catalyzed enantioselective allylic substitution of alkylboranes and $\gamma, \gamma$ disubstituted allyl chlorides.

2.2.2. Optimization. As shown in Table 5, we examined copper complexes prepared from CuOTf.(toluene $)_{0.5}(10 \mathrm{~mol} \%)$ and various DTBM-substituted chiral bisphosphine ligands for catalytic activity, $\gamma$-regioselectivity, and enantioselectivity in the reaction of $\gamma, \gamma$-disubstituted allyl chloride $(E)$-5a with alkylborane 2a in the presence of EtOK in 1,4-dioxane/DCM (1:3) at $25{ }^{\circ} \mathrm{C}$ over $20 \mathrm{~h}(\mathbf{5 a} / \mathbf{2 a} /$ EtOK $1: 1.25: 1.1)$ (Table 5, entries 1-4). ${ }^{20}$ Specifically, the catalyst prepared from the DTBM-substituted TunePHOS-type chiral bisphosphine (L8) did not promote the reaction at all (entry 1$){ }^{21}(R)$-DTBM-BINAP (L3) induced only low catalytic activity, $\gamma$-selectivity, and enantioselectivity (entry 2). ( $R$ )-DTBM-SEGPHOS (L5), which exhibited high performance in the reaction with $\gamma$ monosubstituted primary allyl chlorides (section 2.1), imparted moderate $\gamma$-selectivity $(\gamma / \alpha 6: 1)$ and enantioselectivity $(47 \%$ ee), but the product yield was lower than that with L3 (entry 3). To our delight, the use of $(R)$-DTBM-MeO-BIPHEP (L4) led to a significant improvement in the regioselectivity and enantioselectivity (entry 4). The alkylation occurred at the disubstituted $\gamma$-carbon atom of 5a $(\gamma / \alpha>20: 1)$, constructing the all-carbon quaternary stereogenic center with $83 \%$ ee in favor of the formation of $(S)$-6aa ( $s i$-face attack), albeit still with a low product yield.

The product yield with the $\mathrm{Cu}-(R)$-DTBM-MeO-BIPHEP (L4) system could be increased to $56 \%$ by changing the solvent to THF/DCM (1:3) with the enantioselectivity almost unchanged ( $81 \%$ ee) (Table 5, entry 5$).{ }^{20}$ The yield was further improved to $65 \%$ by conducting the reaction at $15{ }^{\circ} \mathrm{C}$ with an increased amount of the 2a/EtOK reagent (5a/2a/EtOK 1/1.7/1.5) (entry 6).

Table 5. Copper-catalyzed enantioselective allylic substitutions between 2a and $(E)$-5a under various conditions. ${ }^{a}$

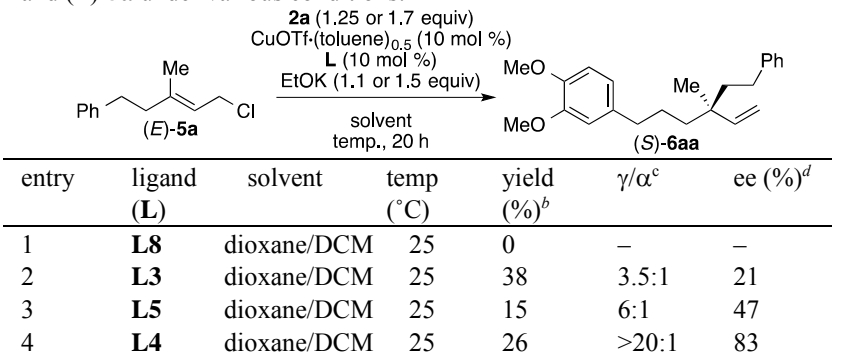

\begin{tabular}{lllllll}
5 & L4 & THF/DCM & 25 & 56 & $>20: 1$ & 81 \\
$6^{e}$ & L4 & THF/DCM & 15 & 65 & $>20: 1$ & 81 \\
\hline
\end{tabular}

${ }^{a}$ The reaction was carried out with $(E)-5 a(0.2 \mathrm{mmol}), 2 a(0.25 \mathrm{mmol})$, CuOTf (toluene) $)_{0.5}(10 \mathrm{~mol} \%)$, ligand (L) $(10 \mathrm{~mol} \%)$, and EtOK $(0.22$ $\mathrm{mmol})$ in solvent $(0.8 \mathrm{~mL})$ for $20 \mathrm{~h}$. Alkylborane 2 was prepared in advance through hydroboration of 1 with the $9-\mathrm{BBN}$ dimer at $60^{\circ} \mathrm{C}(1 \mathrm{~h})$ and used without purification. ${ }^{b}$ Yield of the isolated product. ${ }^{c}$ Determined by ${ }^{1} \mathrm{H}$ NMR analysis of the crude product. ${ }^{d}$ The enantiomeric excess was determined by HPLC analysis. ${ }^{e}$ Reaction on $0.3 \mathrm{mmol}$ scale. 2a $(0.52 \mathrm{mmol})$ and EtOK (0.45 mmol) were used.

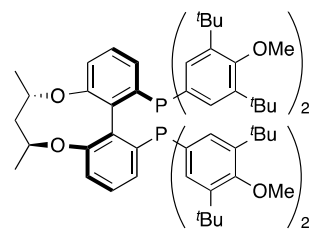

(R)-DTBM-TunePHOS (L8)

2.2.3. Effect of bases. The effect of bases is summarized in Table 6. The use of MeOK instead of EtOK under the conditions for Table 5, entry 4 [CuOTf (toluene) ${ }_{0.5}, \mathbf{L 4}$, dioxane/DCM, 25 $\left.{ }^{\circ} \mathrm{C}\right]$ decreased the product yield $(14 \%$ yield $)$ with the regioselectivity and enantioselectivity unchanged (entry 2 ). The use of $t$-BuOK resulted in no reaction (entry 3 ).

Table 6. Effect of bases

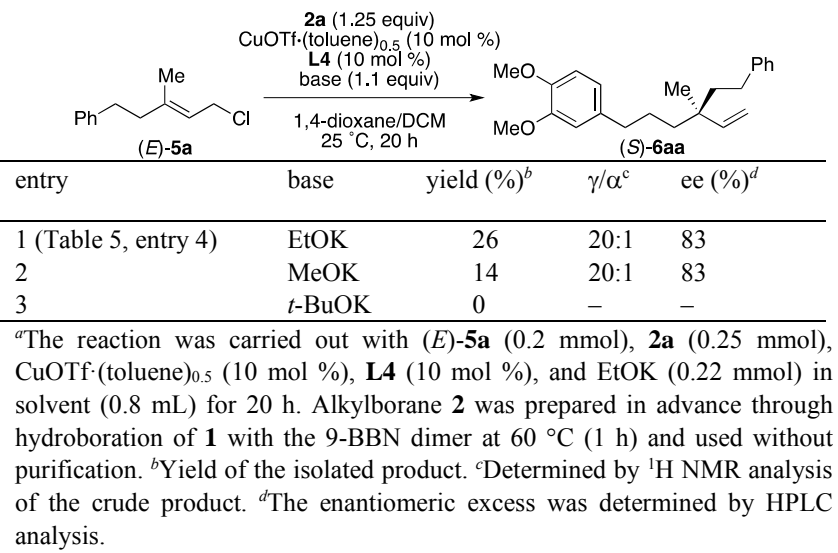

2.2.4. Effect of alkene geometry. The reaction of (Z)-5a under the optimized conditions (the conditions for Table 5, entry 6 ) provided $(R)-6 \mathbf{a a}$, the antipode of the product derived from $(E)$ 5a, with $61 \%$ ee in $85 \%$ yield (Scheme 3). ${ }^{20}$ This enantioselectivity is lower than that for the reaction of $(E)-5 a$ (see section 2.5 for discussion on enantioselection models).

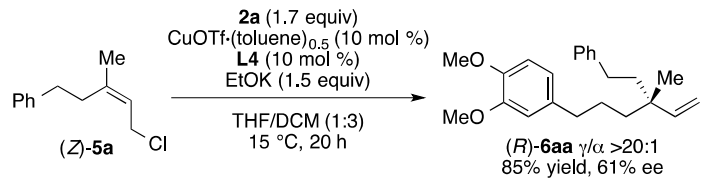

Scheme 3.

2.2.5. Substrate scopes. Various terminal alkenes having different functional groups such as acetal, silyl ether, ester, chloro or benzyl ether in the aliphatic chain were compatible with this protocol as demonstrated by their reactions with $(E)-\mathbf{5 a}$ (Table, 7, entries 1-6). ${ }^{20}$ Ethylene also served as a suitable substrate (entry 7). ${ }^{20}$ This reaction delivered an ethyl group to the 
fully substituted $\gamma$-carbon atom of $\mathbf{5 a}$ with enantioselectivity at a useful level.

The scope of $\gamma, \gamma$-disubstituted allyl chlorides (5) successfully employed is also shown in Table 7 (entries 8-10). ${ }^{20}$ An additional trisubstituted alkene moiety in the allylic substrate $\mathbf{5 b}$ was tolerated during the formation of diene $\mathbf{6 a b}$ (entry 8). The copper catalyst system enabled the enantioselective coupling of allyl chlorides having two alkyl substituents of almost equal steric demands at the $\gamma$-position (entries 9 and 10). For example, allyl chloride 5c having ethyl and phenylethyl groups at the $\gamma$-position reacted with high enantioselectivity $(81 \%$ ee $)$ (entry 9). Replacing the ethyl group at the $\gamma$-position of 5c with a propyl group caused only a slight reduction in the enantioselectivity (entry 10).

Table 7. Scope of enantioselective allylic substitutions with alkylboranes. ${ }^{a}$

entry

${ }^{a}$ The reaction was carried out with $(E)-5(0.2 \mathrm{mmol}), 2(0.34 \mathrm{mmol})$, CuOTf. (toluene) 0.5 (5 mol \%), (R)-DTBM-MeO-BIPHEP (L4) $(10 \mathrm{~mol} \%)$, and EtOK $(0.3 \mathrm{mmol})$ in THF/DCM $(1: 3,0.8 \mathrm{~mL})$ at $15{ }^{\circ} \mathrm{C}$ for $20 \mathrm{~h}$. Alkylborane 2 was prepared in advance through hydroboration of 1 with the 9-BBN dimer at $60{ }^{\circ} \mathrm{C}(1 \mathrm{~h})$ and used without purification. ${ }^{b}$ Yield of the isolated product. ${ }^{c}$ Constitutional isomer ratio $\gamma / \alpha>20: 1$ (determined by ${ }^{1} \mathrm{H}$ NMR analysis of the crude product). ${ }^{d}$ The enantiomeric excess was determined by HPLC analysis. ${ }^{e}$ Constitutional isomer ratio $\gamma / \alpha>10: 1$. ${ }^{f}$ Diastereomeric ratio (1:1).

2.3. Determination of absolute configurations of allylic coupling products. Transformation of the coupling product $4 \mathbf{b b}$ to the $p$-nitrobenzoate derivative $\mathbf{4} \mathbf{b} b \mathbf{b}^{8 \mathrm{c}}$ through ozonolysis and reduction with $\mathrm{NaBH}_{4}$ followed by benzoylation confirmed the $(R)$ absolute configuration of $\mathbf{4 b} \mathbf{b}$ (Scheme 4a). The absolute configuration of allylsilane $4 \mathrm{hg}$ was determined to be $R$ by the optical rotation of $(S)$-undecan-3-ol (4hgc ${ }^{22}$ by alkene reduction followed by Fleming-Tamao oxidation ${ }^{23}$ with retention of configuration (Scheme 4b). The absolute configuration of the coupling product 6la with a quaternary stereogenic center was confirmed by optical rotation of $(S)$-2-ethyl-2-methyl-4-phenyl1-butanol (6laa) obtained by ozonolysis followed by reduction with $\mathrm{NaBH}_{4}$ (Scheme 4c). ${ }^{24}$ Absolute configurations of the other coupling products were assigned by consideration of the stereochemical pathway.
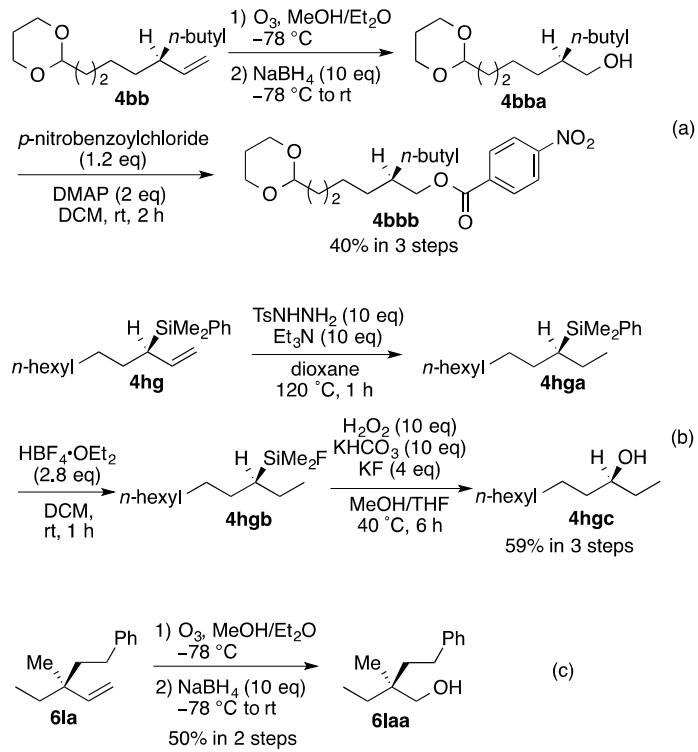

(c)

Scheme 4. Determination of absolute configuration.

2.4. Proposed reaction pathway for the copper-catalyzed allylic alkylations. As proposed for the $\mathrm{Cu}$-catalyzed allyl-alkyl coupling between secondary allylic phosphates and alkylboranes, ${ }^{8 \mathrm{a}-\mathrm{c}}$ an active organocopper species is likely in the form of a neutral organocopper(I) species (C) rather than a monoorganoheterocuprate, since an alkoxide base is consumed for the formation of borate $\mathbf{B}$, and the copper center bearing the alkyl ligand and the bisphosphine ligand is coordinatively saturated upon alkene coordination. Therefore, the addition of alkylcopper(I) species C would occur with anti stereochemistry with respect to the leaving group, being followed by anti- $\beta$ elimination (Figure 1).

Earlier, we proposed that the alkoxyborane, which is derived from the transmetalation between $\mathrm{CuX}$-bisphosphine $[\mathbf{A}, \mathrm{X}=$ $\mathrm{OMe}, \mathrm{OEt}$ or $\mathrm{Cl}$ ] and a trialkyl(alkoxo)borate $\mathbf{B}$, might activate the chloride leaving group through its Lewis-acidic character during the organocopper addition-elimination pathway $[\mathbf{D} / \mathbf{E} \rightarrow$ F-TS/G-TS $\rightarrow \mathbf{H} / \mathbf{I} \rightarrow \mathbf{4}$ or 6] (Figure 1). ${ }^{7}$ However, our ongoing theoretical calculations indicate that the alkoxyborane is not able to coordinate to the chloride leaving group. ${ }^{25}$ 


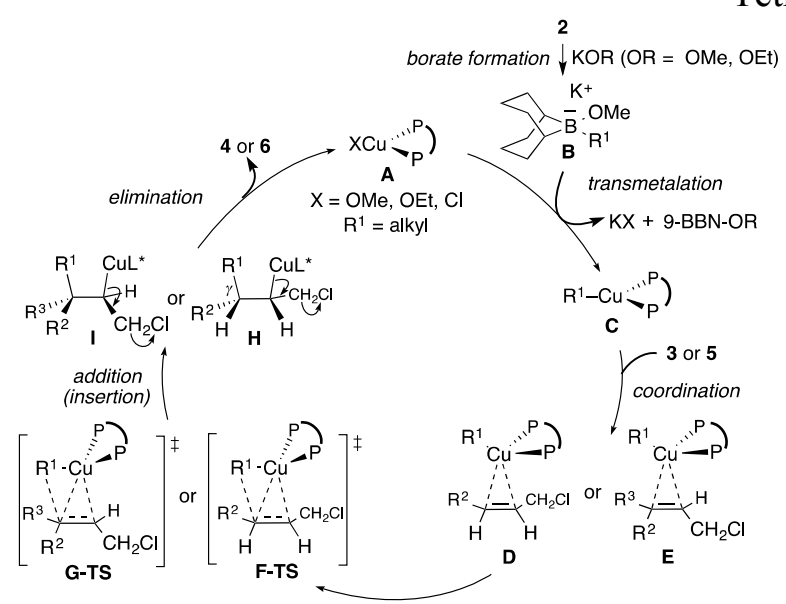

Figure 1. Possible catalytic cycle.

The formation of the $\alpha$-coupling product in the reaction of $\gamma, \gamma-$ disubstituted primary allylic substrates with $(R)$-DTBM-BINAP (L3) or $(R)$-DTBM-SEGPHOS (L5) might be due to the formation of an alkyl(ethoxo)cuprate species upon dissociation of one or two $\mathrm{P}$ atoms of the chiral ligands (Table 5, entries 2 and $3)$. Such cuprate species would undergo oxidative addition with 5 to form an isomeric mixture of ([ $\sigma+\pi]$-allyl)copper(III) species with a $\mathrm{C}-\mathrm{Cu} \sigma$ bond either at the $\alpha$ or $\gamma$ carbon atoms. Reductive elimination of these allylcopper(III) intermediates may form a mixture of the $\alpha$ - and $\gamma$-coupling products as minor products. ${ }^{26,27}$

2.5. Proposed models for enantiodiscrimination. The enantioselection likely occurs at transition states of the $\mathrm{R}^{1}-\mathrm{Cu}$ addition across the $\mathrm{C}-\mathrm{C}$ double bond. Enantioselection models for the reaction of $\gamma$-monosubstituted primary allylic phosphates (Z)-3 are given in Figure 2 (F-TS-1 and F-TS-2). In this model, the copper adopts tetrahedral coordination geometry, in which the axis of the $\mathrm{C}-\mathrm{C}$ double bond is coplanar with the $\mathrm{Cu}-\mathrm{R}^{1}$ bond, $\mathrm{Ar}^{1}$ and $\mathrm{Ar}^{3}$ are equatorial, and $\mathrm{Ar}^{2}$ and $\mathrm{Ar}^{4}$ are axial. Importantly, $\mathrm{Ar}^{1}$ points toward the allyl chloride substrate more significantly than the other equatorial aryl group $\left(\mathrm{Ar}^{3}\right)$. The axial aryl groups $\left(\mathrm{Ar}^{2}\right.$ and $\left.\mathrm{Ar}^{4}\right)$ are much more distal to the substrate. According to these assumptions, F-TS-1 has less steric strain than F-TS-2, because $\mathrm{Ar}^{1}$ is close to both the $\mathrm{R}^{2}$ and $\mathrm{ClCH}_{2}$ substituents in F-TS-2, while F-TS-1 encounters the corresponding steric repulsions only between $\mathrm{Ar}^{3}$ and the $\mathrm{R}^{2}$ substituent, which should be relatively small due to the distal location of $\mathrm{Ar}^{3}$.

In the case of the reaction with $(E)-3, \mathrm{Ar}^{1}$ causes steric repulsions toward either the $\mathrm{ClCH}_{2}$ (F-TS-3) or $\mathrm{R}^{2}$ substituents (F-TS-4) (Figure 2). Consequently, the energy difference between F-TS-3 and F-TS-4 is smaller than that between F-TS-1 and F-TS-2. These considerations explain the more efficient enantioselection in the reaction with the allylic substrate with $Z$ configuration (Table 1 , entry 13 vs. Scheme 2). The observed stereoconvergency from the $Z$ and $E$ allylic substrates affording the product with the identical absolute configuration suggests $\mathrm{Ar}^{1}$ has greater steric interaction with the $\mathrm{R}^{2}$ substituent (F-TS-4) than with the $\mathrm{ClCH}_{2}$ substituent (F-TS-3).
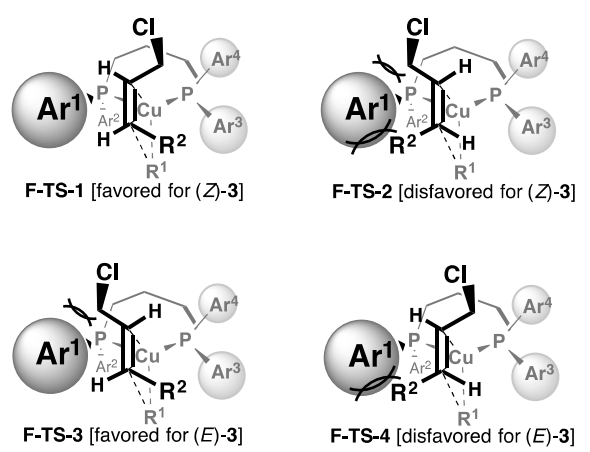

Figure 2. Models for enantiodiscrimination. $\mathrm{Ar}^{1}-\mathrm{Ar}^{4}$ are the $\mathrm{P}$-substituents of L5. The biaryl scaffold of L5 is simplified with a polygonal line.

Enantioselection models for the reaction of $\gamma, \gamma$-disubstituted primary allylic phosphates are depicted in Figure 3 based on the fact that the reactions of $E$ - and $Z$-isomers of 5 a gave the antipodes of 6, respectively, the former showing higher enantioselectivity (Table 5 , entry 6 vs. Scheme 3 ). In the $\pi$ complex E (see Figure 1), the allyl chloride substrate (5) bound to the tetrahedral copper center is in proximity to the two Psubstituents $\mathrm{Ar}^{1}$ and $\mathrm{Ar}^{3}$, which are axial and equatorial substituents, respectively, of the bisphosphine- $\mathrm{Cu}$ chelate ring. The axial substituent $\mathrm{Ar}^{1}$ points toward the substrate more than the equatorial $\mathrm{Ar}^{3} . \mathrm{R}_{1}$ and $\mathrm{R}_{\mathrm{s}}$ indicate the larger and smaller $\gamma$ substituents of $\mathbf{5}$, respectively. E-1, which leads to the major enantiomer of $\mathbf{6}$ in the reaction of $(E)-\mathbf{5}$, has steric repulsion only between $\mathrm{R}_{\mathrm{s}}$ and $\mathrm{Ar}^{3}$, while the corresponding $\pi$-complex $(\mathbf{E}-2)$ leading to the minor enantiomer has larger steric repulsions between the $\mathrm{ClCH}_{2}$ group and $\mathrm{Ar}^{1}$ and between $\mathrm{Ar}^{3}$ and $\mathrm{R}_{1}$. A similar discussion should be applicable for the transition state (G-TS).

In the case of the reaction of $(Z)-5$, the $\pi$-complex (E-3) leading to the major enantiomer, the antipode of the product from E-1, has a steric repulsion between $\mathrm{Ar}^{3}$ and $\mathrm{R}_{\mathrm{l}}$, which should be larger than the steric repulsion that occurs in E-1 $\left(\mathrm{R}_{1}\right.$ vs. $\left.\mathrm{R}_{\mathrm{s}}\right)$ (Figure 3). On the other hand, the steric repulsion between $\mathrm{Ar}^{3}$ and $R_{s}$ in E-4 should be smaller than that between $A r^{3}$ and $R_{1}$ in E-2. These considerations also match the observed trend that the enantioselectivity gradually decreased with the increase of the size of the $\mathrm{R}_{\mathrm{s}}$ substituent of (E)-5 (Table 7, entries 1, 9, and 10). This can be explained by the increasing steric repulsion between $\mathrm{Ar}^{3}$ and $\mathrm{R}_{\mathrm{s}}$ in E-1.

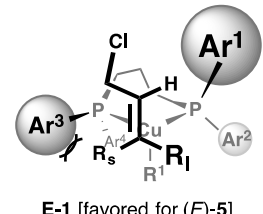

E-1 [favored for $(E)-5]$

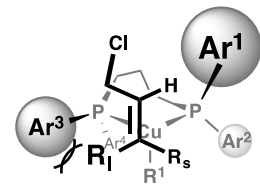

E-3 [favored for (Z)-5]

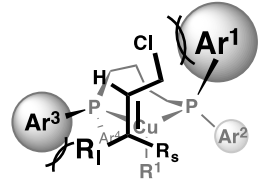

E-2 [disfavored for $(E)-5]$

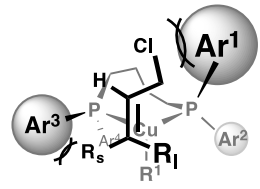

E-4 [disfavored for (Z)-5]
Figure 3. Proposed models for enantiodiscrimination. $\mathrm{R}_{\mathrm{I}}$ and $\mathrm{R}_{\mathrm{S}}$ are the larger and smaller $\gamma$-substituents of 5, respectively. $\mathrm{Ar}^{1}-\mathrm{Ar}^{4}$ are the P-substituents of L4. The biaryl scaffold of L4 is simplified with a polygonal line. 


\section{Conclusion}

Here we have presented full details of our work on alkylboranes, which we have introduced as new reagents for copper-catalyzed $\mathrm{S}_{\mathrm{N}} 2$ '-type enantioselective allylic substitutions. The copper catalysis delivered enantioenriched chiral products containing tertiary or quaternary carbon stereogenic centers branched with functionalized $\mathrm{sp}^{3}$-alkyl groups. The wide availability of alkylboranes via the established alkene hydroboration reaction is an attractive feature of these transformations. Various functional groups are tolerated in the substrates. The introduction of DTBM substituents on the phosphorus atoms of chiral bisphosphines was important for promotion of the reaction. The catalytic activity, $\gamma$-selectivity, and enantioselectivity of the reaction were very sensitive to the dihedral angle of the axially chiral biaryl scaffolds in the $\mathrm{Cu}(\mathrm{I})$ bisphosphine complexes. A reaction pathway involving additionelimination of a neutral alkylcopper(I) species with the allyl chloride substrate is proposed.

\section{Experimental section}

\subsection{General.}

NMR spectra were recorded on a Varian Gemini 2000 spectrometer, operating at $300 \mathrm{MHz}$ for ${ }^{1} \mathrm{H} \mathrm{NMR}$ and $75.4 \mathrm{MHz}$ for ${ }^{13} \mathrm{C}$ NMR, and a JEOL ECX-400, operating at $100.5 \mathrm{MHz}$ for ${ }^{13} \mathrm{C}$ NMR. Chemical shift values for ${ }^{1} \mathrm{H}$ and ${ }^{13} \mathrm{C}$ are referenced to $\mathrm{Me}_{4} \mathrm{Si}$ and the residual solvent resonances, respectively. Chemical shifts are reported in $\delta$ ppm. Mass spectra were obtained with Thermo Fisher Scientific Exactive, JEOL JMST100LP or JEOL JMS-700TZ at the Instrumental Analysis Division, Equipment Management Center, Creative Research Institution, Hokkaido University. Elemental analysis was performed at the Instrumental Analysis Division, Equipment Management Center, Creative Research Institution, Hokkaido University. HPLC analyses were conducted on a HITACHI ELITE LaChrom system with a HITACHI L-2455 diode array detector. IR spectra were recorded on a Perkin-Elmer Spectrum One. TLC analyses were performed on commercial glass plates bearing $0.25-\mathrm{mm}$ layer of Merck Silica gel $60 \mathrm{~F}_{254}$. Silica gel (Kanto Chemical Co., Silica gel $60 \mathrm{~N}$, spherical, neutral) was used for column chromatography. Melting points were measured on a Yanaco MP-500D apparatus. Gel permeation chromatography (GPC) was performed by LC-908 (Japan Analytical Industry Ltd., two in-line JAIGEL-2H, $\mathrm{CHCl}_{3}, 3.5$ $\mathrm{mL} / \mathrm{min}$, UV and RI detectors).

All reactions were carried out under nitrogen or argon atmosphere. Materials were obtained from commercial suppliers or prepared according to standard procedures unless otherwise noted. 9-Borabicyclo[3,3,1]nonane dimer $(9-\mathrm{BBN}-\mathrm{H})_{2}$, CuOTf.(toluene) 0.5 , MeOK, EtOK, $(R)$-DTBM-MeO-BIPHEP (L4) and $(R)$-DTBM-BINAP (L3) were purchased from Aldrich Chemical Co., stored under nitrogen, and used as it is. $(R)$ DTBM-SEGPHOS (L5) was purchased from Strem Chemicals Inc., stored under nitrogen, and used as it is. (R)-DTBMTunePHOS (L8) was prepared according to the literture procedure. ${ }^{21}$ Dichloromethane (DCM) was purchased from Kanto Chemical Co., stored over $4 \AA$ molecular sieves under nitrogen. 1,4-Dioxane was purchased from Kanto Chemical Co., distilled from sodium/benzophenone and stored over $4 \AA$ molecular sieves under nitrogen. Alkenes 1a-I are well known compounds. Allyl chrolides 3d, $(E)-\mathbf{5 a}, \mathbf{b}$ are found in the literture. ${ }^{28}$

\subsection{Preparation of Allyl Chlorides.}

4.2.1. Preparation of (Z)-Allyl Chlorides 3a-c, e and $f$. Addition of the lithium acetylides to formaldehyde gave the corresponding propargylic alcohols. Next, Lindlar reduction followed by chlorination (NCS, $\mathrm{PPh}_{3}, \mathrm{DCM}, \mathrm{rt}$ ) afforded the allylic chlorides $\mathbf{3 a}-\mathbf{c}$, $\mathbf{e}$ and $\mathbf{f}$.

4.2.2. Preparation of (Z)-1-Dimethylphenysilyl-3-chloro-1pentene (3g). THP-protection of 2-propyn-1-ol followed by silylation gave $\gamma$-silylated propargylic alcohol derivative. Next, DIBAL-H reduction followed by deprotection ( $p$ - TsOH, $\mathrm{MeOH}$ ) afforded $\gamma$-silylated allylic alcohol. Finally, $3 \mathbf{g}$ was prepared by chlorination (NCS, $\mathrm{PPh}_{3}, \mathrm{DCM}, \mathrm{rt}$ ) of the $\gamma$-silylated allylic alcohol.

4.2.3. Preparation of $\gamma, \gamma$-Disubstituted (E)-Allyl Chlorides 5a, c and $\mathbf{d}$. The preparation of $\mathbf{5 a}$ is representative. To a solution of $\mathrm{CuI}(1.8 \mathrm{~g}, 9.6 \mathrm{mmol})$ and TMEDA $(3.6 \mathrm{~mL}, 24 \mathrm{mmol})$ in THF $(1.0 \mathrm{~mL})$ was added 2-phenylethylmagnesium bromide $(0.7 \mathrm{M}$ in THF, $13.7 \mathrm{~mL}, 9.6 \mathrm{mmol})$ at $-40{ }^{\circ} \mathrm{C}$, and the resulting mixture was stirred at $-40{ }^{\circ} \mathrm{C}$ for $30 \mathrm{~min}$. To the mixture was added ethyl 2-butynoate $(0.9 \mathrm{~g}, 8 \mathrm{mmol})$ at $-78{ }^{\circ} \mathrm{C}$, and the mixture was stirred at $-78{ }^{\circ} \mathrm{C}$ for $2 \mathrm{~h}$. Saturated $\mathrm{NH}_{4} \mathrm{Cl}$ aq was added and the mixture was allowed to warm to room temperature. The resulting slurry was diluted with EtOAc $(50 \mathrm{~mL})$ and washed with $\mathrm{H}_{2} \mathrm{O}$ and brine. The organic layer was separated and dried over $\mathrm{MgSO}_{4}$. Then, the drying agent was removed by filtration, and the resulting solution was evaporated under reduced pressure. The residue was purified by flash chromatography on silica gel (0$10 \%$ EtOAc/hexane) provided ethyl $(E)$-3-methyl-5-phenyl-2pentenoate $(1.7 \mathrm{~g}, 7.6 \mathrm{mmol})$ in $95 \%$ yield.

To a stirred solution of ethyl (E)-3-methyl-5-phenyl-2pentenoate $(1.7 \mathrm{~g}, 7.6 \mathrm{mmol})$ in DCM was dropped DIBAL-H (16.4 $\mathrm{mL}$ in $1.02 \mathrm{M}$ hexane solution, $16.7 \mathrm{mmol}$ ) at $-78{ }^{\circ} \mathrm{C}$ and the reaction was continued for $30 \mathrm{~min}$ at the same temperature. Sat. $\mathrm{NH}_{4} \mathrm{Cl}$ was added and the mixture was vigorously stirred for $10 \mathrm{~min}$. Solid was filtered through celite pad and the filtrate was extracted with ether. The crude product was purified by flash chromatography on silica gel $(10-20 \%$ EtOAc/hexane) to give (E)-3-methyl-5-phenyl-2-penten-1-ol (1.2 g, $6.6 \mathrm{mmol})$ in $87 \%$ yield.

To a solution of $(E)$-3-methyl-5-phenyl-2-penten-1-ol (1.2g, $6.6 \mathrm{mmol})$ in DCM $(13.2 \mathrm{~mL})$, NCS (1.0 g, $7.3 \mathrm{mmol})$ and $\mathrm{PPh}_{3}$ $(2.0 \mathrm{~g}, 7.9 \mathrm{mmol})$ were sequentially added at $0{ }^{\circ} \mathrm{C}$. After being stirred at $\mathrm{rt}$ for $2 \mathrm{~h}$, the solvent was removed under reduced pressure, and then residue was filtered through a pad of celite with EtOAc as an eluent. The filtrate was evaporated under reduced pressure. The residue was purified through flash chromatography on silica gel (hexane) followed by Kugelrohr disitillation provided $5 \mathrm{a}(1.1 \mathrm{~g}, 5.6 \mathrm{mmol})$ in $80 \%$ yield.

4.2.4. Preparation of $\gamma, \gamma$-Disubstituted $(E)$-Allyl Chloride $5 b$. To a solution of geraniol $(1.5 \mathrm{~g}, 10 \mathrm{mmol})$ in DCM $(20 \mathrm{~mL})$, NCS $(1.5 \mathrm{~g}, 11 \mathrm{mmol})$ and $\mathrm{PPh}_{3}(3.1 \mathrm{~g}, 12 \mathrm{mmol})$ were sequentially added at $0{ }^{\circ} \mathrm{C}$. After being stirred at $\mathrm{rt}$ for $2 \mathrm{~h}$, the solvent was removed under reduced pressure, and then residue was filtered through a pad of celite with hexane as an eluent. The filtrate was evaporated under reduced pressure. The residue was purified by Kugelrohr disitillation to provide $5 \mathbf{b}(1.4 \mathrm{~g}, 8 \mathrm{mmol})$ in $80 \%$ yield.

4.3. Procedures for Copper-Catalyzed Enantioselective Allylic Substitution with Alkylboranes 
4.3.1. Typical Procedure for Copper-catalyzed Allylic Substitutions with $\gamma$-Monosubstituted Primary Allyl Chlorides (Table 3, entry 1). 2-(3-Buten-1-yl)-1,3-dioxane (1b) $(196.6 \mu \mathrm{L}, 1.3 \mathrm{mmol})$ and $(9-\mathrm{BBN}-\mathrm{H})_{2}(151.2 \mathrm{mg}, 0.625 \mathrm{mmol})$ were placed in a vial containing a magnetic stirring bar. The vial was sealed with a Teflon ${ }^{\circledR}$-coated silicon rubber septum and the vial was evacuated and filled with argon. 1,4-Dioxane $(1.0 \mathrm{~mL})$ was added to the vial, and then the mixture was stirred at $60^{\circ} \mathrm{C}$ for $1 \mathrm{~h}$ to prepare an alkylborane. On the other hand, CuOTf.(toluene $)_{0.5}(26 \mathrm{mg}, 0.1 \mathrm{mmol}),(R)$-DTBM-SEGPHOS (L5) $(118 \mathrm{mg}, 0.1 \mathrm{mmol})$ and $\mathrm{MeOK}(77 \mathrm{mg}, 1.1 \mathrm{mmol})$ were placed in another vial. The vial was sealed with a Teflon ${ }^{\circledR}$-coated silicon rubber septum and the vial was evacuated and filled with argon. After DCM $(3.0 \mathrm{~mL})$ was added to the vial, the mixture was stirred at $25{ }^{\circ} \mathrm{C}$ for $1 \mathrm{~h}$. Next, the alkylborane solution was transferred to the vial containing a $\mathrm{Cu}(\mathrm{I})-\mathbf{L 5}$ complex. Then, allyl chloride $3 \mathbf{b}$ (132.6 mg, $1.0 \mathrm{mmol})$ was added. After $72 \mathrm{~h}$ stirring at $15{ }^{\circ} \mathrm{C}$, diethyl ether was added to the mixture. The mixture was filtered through a short plug of silica gel, which was then washed with diethyl ether. After the solvent was removed under reduced pressure, flash chromatography on silica gel (0$5 \% \mathrm{EtOAc} /$ hexane $)$ provided $4 \mathbf{b b}(223.6 \mathrm{mg}, 0.93 \mathrm{mmol})$ in $93 \%$ yield.

4.3.2. Typical Procedure for Synthesis of Chiral Allylsilanes (Table 4, entry 5). 6-Chloro-1-hexene (1i) $(172 \mu \mathrm{L}, 1.3 \mathrm{mmol})$ and $(9-\mathrm{BBN}-\mathrm{H})_{2}(151.2 \mathrm{mg}, 0.625 \mathrm{mmol})$ were placed in a vial containing a magnetic stirring bar. The vial was sealed with a Teflon ${ }^{\circledR}$-coated silicon rubber septum and the vial was evacuated and filled with argon. 1,4-Dioxane $(1.0 \mathrm{~mL})$ was added to the vial, and then the mixture was stirred at $60^{\circ} \mathrm{C}$ for $1 \mathrm{~h}$ to prepare an alkylborane. On the other hand, CuOTf (toluene $)_{0.5}(26 \mathrm{mg}$, $0.1 \mathrm{mmol}),(R)$-DTBM-SEGPHOS (L5) $(118 \mathrm{mg}, 0.1 \mathrm{mmol})$ and $\mathrm{MeOK}(77 \mathrm{mg}, 1.1 \mathrm{mmol})$ were placed in another vial. The vial was sealed with a Teflon ${ }^{\circledR}$-coated silicon rubber septum and the vial was evacuated and filled with argon. After DCM (3.0 mL) was added to the vial, the mixture was stirred at $25{ }^{\circ} \mathrm{C}$ for $1 \mathrm{~h}$. Next, the alkylborane solution was transferred to the vial containing a $\mathbf{C u}(\mathrm{I})-\mathbf{L} 5$ complex. Then, allyl chloride $\mathbf{3 g}(211 \mathrm{mg}$, $1.0 \mathrm{mmol}$ ) was added. After $48 \mathrm{~h}$ stirring at $15{ }^{\circ} \mathrm{C}$, diethyl ether was added to the mixture. The mixture was filtered through a short plug of silica gel, which was then washed with diethyl ether. After the solvent was removed under reduced pressure, flash chromatography on silica gel (hexane) provided 4ig (259.5 $\mathrm{mg}, 0.88 \mathrm{mmol}$ ) in $88 \%$ yield.

4.3.3. Typical Procedure for Construction of Quaternary Carbon Stereogenic Centers using $\gamma, \gamma$-Disubstituted Primary Allyl Chlorides (Table 5, entry 6). 3,4-Dimethoxy-1allylbenzene (1a) $(93.4 \mu \mathrm{L}, 0.54 \mathrm{mmol})$ and $(9-\mathrm{BBN}-\mathrm{H})_{2}(64.2$ $\mathrm{mg}, 0.26 \mathrm{mmol})$ were placed in a vial containing a magnetic stirring bar. The vial was sealed with a Teflon ${ }^{\circledR}$-coated silicon rubber septum and the vial was evacuated and filled with argon. THF $(0.3 \mathrm{~mL})$ was added to the vial, and then the mixture was stirred at $60{ }^{\circ} \mathrm{C}$ for $1 \mathrm{~h}$ to prepare an alkylborane. Meanwhile, CuOTf (toluene) $0.5 \quad(7.8 \mathrm{mg}, 0.03 \mathrm{mmol}),(R)$-DTBM-MeOBIPHEP (L4) (35.5 mg, $0.03 \mathrm{mmol}$ ) and EtOK (39.9 mg, 0.45 mmol) were placed in another vial. This vial was sealed with a Teflon ${ }^{\circledR}$-coated silicon rubber septum and then evacuated and filled with argon. After DCM $(0.9 \mathrm{~mL})$ was added to the vial, the mixture was stirred at $25{ }^{\circ} \mathrm{C}$ for $1 \mathrm{~h}$. Next, the alkylborane solution was transferred to the vial containing the $\mathrm{Cu}(\mathrm{I})-\mathbf{L} 4$ complex. Next, allyl chloride $(E)-5 a(58.5 \mathrm{mg}, 0.3 \mathrm{mmol})$ was added. After $20 \mathrm{~h}$ stirring at $15^{\circ} \mathrm{C}$, diethyl ether was added to the mixture. The mixture was filtered through a short plug of silica gel, which was then washed with diethyl ether. After the solvent was removed under reduced pressure, flash chromatography on silica gel (0-3\% EtOAc/hexane) provided 6aa $(66.0 \mathrm{mg}, 0.20$ $\mathrm{mmol}$ ) at $81 \%$ ee in $65 \%$ yield.

\subsection{Characterization Data}

4.4.1. (Z)-(5-Chloro-3-penten-1-yl)benzene (3a). Colorless Oil. IR (neat) 697, 742, 1250, 1453, 1496, 1652, 2931, $3027 \mathrm{~cm}^{-1} .{ }^{1} \mathrm{H}$ NMR $\left(300 \mathrm{MHz}, \mathrm{CDCl}_{3}\right) \delta 2.41-2.47(\mathrm{~m}, 2 \mathrm{H}), 2.71(\mathrm{t}, J=7.2 \mathrm{~Hz}$, $2 \mathrm{H}), 3.94-4.01(\mathrm{~m}, 2 \mathrm{H}), 5.60-5.71(\mathrm{~m}, 2 \mathrm{H}), 7.17-7.25(\mathrm{~m}, 3 \mathrm{H})$, 7.27-7.32 (m, 2H). ${ }^{13} \mathrm{C}$ NMR $\left(75.4 \mathrm{MHz}, \mathrm{CDCl}_{3}\right)$ $39.2,126.0,126.1,128.5,128.5,134.1,141.3$. HRMS-EI $(\mathrm{m} / \mathrm{z})$ : $[\mathrm{M}]^{+}$calcd for $\mathrm{C}_{11} \mathrm{H}_{13} \mathrm{Cl}, 180.07058$; found, 180.07060 .

4.4.2. (Z)-1-Chloro-2-heptene (3b). Colorless Oil. IR (neat) 756, $1250,1458,1652,2930 \mathrm{~cm}^{-1} .{ }^{1} \mathrm{H}$ NMR $\left(300 \mathrm{MHz}, \mathrm{CDCl}_{3}\right) \delta 0.91$ (t, $J=7.2 \mathrm{~Hz}, 3 \mathrm{H}), 1.27-1.39(\mathrm{~m}, 4 \mathrm{H}), 2.09-2.18(\mathrm{~m}, 2 \mathrm{H}), 4.10$ $(\mathrm{d}, J=4.5 \mathrm{~Hz}, 2 \mathrm{H}), 5.58-5.69(\mathrm{~m}, 2 \mathrm{H}) .{ }^{13} \mathrm{C} \mathrm{NMR}(75.4 \mathrm{MHz}$, $\left.\mathrm{CDCl}_{3}\right) \delta 13.8,22.2,26.7,31.3,39.5,125.1,135.6$. HRMS-EI $(\mathrm{m} / \mathrm{z})$ : $[\mathrm{M}]^{+}$calcd for $\mathrm{C}_{7} \mathrm{H}_{13} \mathrm{Cl}, 132.07058$; found, 132.07047 .

4.4.3. (Z)-1,7-Dichloro-2-heptene (3c). Colorless Oil. IR (neat) $756,1251,1454,1652,2941 \mathrm{~cm}^{-1} .{ }^{1} \mathrm{H}$ NMR $\left(300 \mathrm{MHz}, \mathrm{CDCl}_{3}\right)$ $\delta 1.51-1.61(\mathrm{~m}, 2 \mathrm{H}), 1.75-1.85(\mathrm{~m}, 2 \mathrm{H}), 2.13-2.20(\mathrm{~m}, 2 \mathrm{H}), 3.55$ (t, $J=6.6 \mathrm{~Hz}, 2 \mathrm{H}), 4.09$ (d, $J=7.2 \mathrm{~Hz}, 2 \mathrm{H}), 5.58-5.72(\mathrm{~m}, 2 \mathrm{H})$. ${ }^{13} \mathrm{C}$ NMR $\left(75.4 \mathrm{MHz}, \mathrm{CDCl}_{3}\right) \delta$

125.9, 134.7. HRMS-EI $(\mathrm{m} / \mathrm{z})$ : $[\mathrm{M}]^{+}$calcd for $\mathrm{C}_{7} \mathrm{H}_{12} \mathrm{Cl}_{2}$, 166.03161; found, 166.03168 .

4.4.4. (Z)-(3-Chloro-1-propen-1-yl)cyclohexane (3e). Colorless Oil. IR (neat) 766, 890, 1249, 1448, 1651, 2850, $2924 \mathrm{~cm}^{-1} .{ }^{1} \mathrm{H}$ NMR (300 MHz, $\left.\mathrm{CDCl}_{3}\right) \delta 1.03-1.36(\mathrm{~m}, 5 \mathrm{H}), 1.55-1.75(\mathrm{~m}$, $5 \mathrm{H}), 2.31-2.34(\mathrm{~m}, 1 \mathrm{H}), 4.11(\mathrm{~d}, J=7.2 \mathrm{~Hz}, 2 \mathrm{H}), 5.43-5.57(\mathrm{~m}$, 2H). ${ }^{13} \mathrm{C}$ NMR (75.4 MHz, $\left.\mathrm{CDCl}_{3}\right) \delta 25.6,25.7,32.9,36.2,39.8$, 123.3 , 141.4. HRMS-EI $(\mathrm{m} / \mathrm{z})$ : $[\mathrm{M}]^{+}$calcd for $\mathrm{C}_{9} \mathrm{H}_{15} \mathrm{Cl}$, 158.08623; found, 158.08626 .

4.4.5. (Z)-tert-Butyl[(7-chloro-5-hepten-1yl)oxy]dimethylsilane (3f). Colorless Oil. IR (neat) 773, 833, 1097, 1252, 1472, 2858, $2930 \mathrm{~cm}^{-1} .{ }^{1} \mathrm{H}$ NMR $\left(300 \mathrm{MHz}, \mathrm{CDCl}_{3}\right)$ $\delta 0.05(\mathrm{~s}, 3 \mathrm{H}), 0.06(\mathrm{~s}, 3 \mathrm{H}), 0.89(\mathrm{~s}, 9 \mathrm{H}), 1.41-1.56(\mathrm{~m}, 4 \mathrm{H})$, $2.11-2.18(\mathrm{~m}, 2 \mathrm{H}), 3.62(\mathrm{t}, J=6.0 \mathrm{~Hz}, 2 \mathrm{H}), 4.10(\mathrm{~d}, J=6.6 \mathrm{~Hz}$, $2 \mathrm{H}), 5.62-5.66(\mathrm{~m}, 2 \mathrm{H}) .{ }^{13} \mathrm{C}$ NMR $\left(75.4 \mathrm{MHz}, \mathrm{CDCl}_{3}\right) \delta-5.5$. $18.2,25.5,25.9,26.7,32.2,39.4,62.8,125.4,135.4$. HRMS-EI $(\mathrm{m} / \mathrm{z})$ : $[\mathrm{M}-\mathrm{Cl}]^{+}$calcd for $\mathrm{C}_{13} \mathrm{H}_{27} \mathrm{OSi}, 227.1831$; found, 227.1832.

4.4.6. (Z)-1-Dimethylphenysilyl-3-chloro-1-pentene (3g). Colorless Oil. IR (neat) 698, 782, 818, 1111, 1250, 1427, 1604, $2958 \mathrm{~cm}^{-1} .{ }^{1} \mathrm{H}$ NMR $\left(300 \mathrm{MHz}, \mathrm{CDCl}_{3}\right) \delta 0.42(\mathrm{~s}, 6 \mathrm{H}), 3.95(\mathrm{~d}, J$ $=7.8 \mathrm{~Hz}, 2 \mathrm{H}), 5.92(\mathrm{~d}, J=14.1 \mathrm{~Hz}, 1 \mathrm{H}), 6.51(\mathrm{dt} J=14.1,7.8$ $\mathrm{Hz}, 1 \mathrm{H}), 7.36-7.38(\mathrm{~m}, 3 \mathrm{H}), 7.53-7.56(\mathrm{~m}, 2 \mathrm{H}) .{ }^{13} \mathrm{C}$ NMR $(75.4$ $\left.\mathrm{MHz}, \mathrm{CDCl}_{3}\right) \delta$

144.0. HRMS-EI $(\mathrm{m} / z):\left[\mathrm{M}-\mathrm{CH}_{3}\right]^{+}$calcd for $\mathrm{C}_{10} \mathrm{H}_{12} \mathrm{ClSi}$, 195.0397; found, 195.0399.

4.4.7. (S)-1,2-Dimethoxy-4-(4-phenethyl-5-hexen-1-yl)benzene (4aa). The product 4aa was purified by flash chromatography on silica gel $\left(0-10 \%\right.$ EtOAc/hexane) followed by $\mathrm{GPC}\left(\mathrm{CHCl}_{3}\right)$ [59\% isolated yield from (Z)-3a]. Colorless Oil. IR (neat) 699, $749,1030,1140,1235,1515,1591,2932 \mathrm{~cm}^{-1} .{ }^{1} \mathrm{H}$ NMR $(300$ $\left.\mathrm{MHz}, \mathrm{CDCl}_{3}\right) \delta 1.29-1.74(\mathrm{~m}, 6 \mathrm{H}), 1.98-2.06(\mathrm{~m}, 1 \mathrm{H}), 2.45$ $2.60(\mathrm{~m}, 2 \mathrm{H}), 2.62-2.69(\mathrm{~m}, 2 \mathrm{H}), 3.85(\mathrm{~s}, 3 \mathrm{H}), 3.86(\mathrm{~s}, 3 \mathrm{H})$, $4.97-5.07(\mathrm{~m}, 2 \mathrm{H}), 5.57$ (dt, $J=17.1,9.6 \mathrm{~Hz}, 1 \mathrm{H}), 6.69$ (d, $J=$ $6.6 \mathrm{~Hz}, 2 \mathrm{H}), 6.78(\mathrm{~d}, J=8.7 \mathrm{~Hz}, 1 \mathrm{H}), 7.15-7.19(\mathrm{~m}, 3 \mathrm{H}), 7.25$ $7.30(\mathrm{~m}, 2 \mathrm{H}) .{ }^{13} \mathrm{C}$ NMR $\left(75.4 \mathrm{MHz}, \mathrm{CDCl}_{3}\right) \delta$

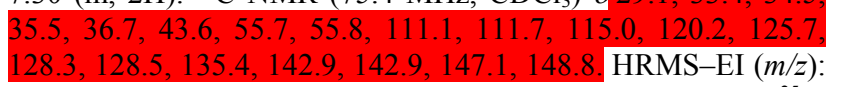
$[\mathrm{M}]^{+}$calcd for $\mathrm{C}_{22} \mathrm{H}_{28} \mathrm{O}_{2}, 324.20893$; found, 324.20883. $[\alpha]_{\mathrm{D}}^{25}-$ $0.75\left(77 \%\right.$ ee, $\left.c 1.03, \mathrm{CHCl}_{3}\right)$. HPLC analysis [CHIRALCEL ${ }^{\circledR}$ 
OD-3 column, $4.6 \mathrm{~mm} \times 250 \mathrm{~mm}$, Daicel Chemical Industries, hexane $/ 2$-propanol $=97: 3,0.5 \mathrm{~mL} / \mathrm{min}, 40{ }^{\circ} \mathrm{C}, 254 \mathrm{~nm} \mathrm{UV}$ detector, retention time $=19.5 \mathrm{~min}$ for $R$ isomer and $20.9 \mathrm{~min}$ for $S$ isomer] revealed that the enantiomeric excess of 4 aa was $77 \%$. The absolute configuration of 4 aa was assigned by consideration of the stereochemical pathway.

4.4.8. (R)-2-(5-Vinylnonyl)-1,3-dioxane (4bb). The product $4 \mathbf{b b}$ was purified by flash chromatography on silica gel $(0-5 \%$ EtOAc/hexane) (93\% isolated yield). Colorless Oil. IR (neat) 908 , 995, 1144, 1640, 2851, $2925 \mathrm{~cm}^{-1} .{ }^{1} \mathrm{H}$ NMR $\left(300 \mathrm{MHz}, \mathrm{CDCl}_{3}\right) \delta$ $0.87(\mathrm{t}, J=7.2 \mathrm{~Hz}, 3 \mathrm{H}), 1.17-1.36(\mathrm{~m}, 13 \mathrm{H}), 1.54-1.60(\mathrm{~m}, 2 \mathrm{H})$, $1.85-2.00(\mathrm{~m}, 1 \mathrm{H}), 2.01-2.16(\mathrm{~m}, 1 \mathrm{H}), 3.76(\mathrm{td}, J=12.0,2.1 \mathrm{~Hz}$, $2 \mathrm{H}), 4.10(\mathrm{dd}, J=10.5,4.8 \mathrm{~Hz}, 2 \mathrm{H}), 4.50(\mathrm{t}, J=5.1 \mathrm{~Hz}, 1 \mathrm{H})$, $4.89-4.96(\mathrm{~m}, 2 \mathrm{H}), 5.51$ (ddd, $J=16.8,10.5,8.7 \mathrm{~Hz}, 1 \mathrm{H}) .{ }^{13} \mathrm{C}$ NMR $\left(75.4 \mathrm{MHz}, \mathrm{CDCl}_{3}\right) \delta 14.0,22.7,24.0,25.7,26.9,29.3$, 34.6, 34.8, 35.1, 43.9, 66.9, 102.5, 113.9, 143.7. HRMS-EI $(\mathrm{m} / \mathrm{z}):[\mathrm{M}-\mathrm{H}]^{+}$calcd for $\mathrm{C}_{15} \mathrm{H}_{27} \mathrm{O}_{2}, 239.20110$; found, 239.20061 . $[\alpha]_{\mathrm{D}}^{25}+0.33\left(c 1.20, \mathrm{CHCl}_{3}\right)$. The ee value $(88 \%$ ee $)$ was determined by chiral HPLC analysis of the $p$-nitrobenzoate derivative obtained by the ozonolysis, reduction with $\mathrm{NaBH}_{4}$ followed by benzoylation ( $p$-nitrobenzoylchloride, DMAP, DCM, rt) from $4 \mathbf{b b}$ [CHIRALCEL ${ }^{\circledR}$ OD-3 column, $4.6 \mathrm{~mm} \times 250$ $\mathrm{mm}$, Daicel Chemical Industries, hexane/2-propanol $=99: 1,0.5$ $\mathrm{mL} / \mathrm{min}, 40{ }^{\circ} \mathrm{C}, 254 \mathrm{~nm} \mathrm{UV}$ detector, retention time $=42.3 \mathrm{~min}$ for $R$ isomer and $44.2 \mathrm{~min}$ for $S$ isomer]. The literature data of the $p$-nitrobenzoate derivative $4 \mathbf{b b b}$ confirmed the $(R)$ absolute configuration of $\mathbf{4 b b}$ (Scheme $4 a){ }^{8 c}$

4.4.9. (S)-2-(10-Chloro-6-vinyldecyl)-1,3-dioxane (4cc). The product 4cc was purified by flash chromatography on silica gel $\left(0-5 \%\right.$ EtOAc/hexane) followed by GPC $\left(\mathrm{CHCl}_{3}\right)(71 \%$ isolated yield). Colorless Oil. IR (neat) 910, 995, 1144, 1640, 2851, 2925 $\mathrm{cm}^{-1} .{ }^{1} \mathrm{H}$ NMR (300 MHz, $\left.\mathrm{CDCl}_{3}\right) \delta 1.21-1.47(\mathrm{~m}, 13 \mathrm{H}), 1.56-$ $1.69(\mathrm{~m}, 2 \mathrm{H}), 1.71-1.80(\mathrm{~m}, 2 \mathrm{H}), 1.91-1.93(\mathrm{~m}, 1 \mathrm{H}), 2.00-2.14$ $(\mathrm{m}, 1 \mathrm{H}), 3.52(\mathrm{t}, J=6.6 \mathrm{~Hz}, 2 \mathrm{H}), 3.76(\mathrm{td}, J=12.3,2.4 \mathrm{~Hz}, 2 \mathrm{H})$, $4.08-4.12(\mathrm{~m}, 2 \mathrm{H}), 4.50(\mathrm{t}, J=5.2 \mathrm{~Hz}, 1 \mathrm{H}), 4.93(\mathrm{dd}, J=16.5$, $2.1 \mathrm{~Hz}, 1 \mathrm{H}), 4.96(\mathrm{dd}, J=10.2,2.1 \mathrm{~Hz}, 1 \mathrm{H}), 5.49$ (ddd, $J=16.5$, 10.2, 8.7 Hz, 1H). ${ }^{13} \mathrm{C}$ NMR $\left(75.4 \mathrm{MHz}, \mathrm{CDCl}_{3}\right) \delta$

HRMS-EI $(\mathrm{m} / \mathrm{z})$ : $[\mathrm{M}-\mathrm{H}]^{+}$calcd for $\mathrm{C}_{16} \mathrm{H}_{28} \mathrm{ClO}_{2}$, 287.17778; found, 287.17776. $[\alpha]_{\mathrm{D}}{ }^{25}+4.80\left(c 1.10, \mathrm{CHCl}_{3}\right)$. The ee value $(83 \%$ ee) was determined by chiral HPLC analysis of the $p$-nitrobenzoate derivative obtained by the ozonolysis, reduction with $\mathrm{NaBH}_{4}$ followed by benzoylation ( $p$ nitrobenzoylchloride, DMAP, DCM, rt) from 4cc [CHIRALCEL ${ }^{\circledR}$ OD-3 column, $4.6 \mathrm{~mm} \times 250 \mathrm{~mm}$, Daicel Chemical Industries, hexane/2-propanol $=97: 3,0.5 \mathrm{~mL} / \mathrm{min}, 40$ ${ }^{\circ} \mathrm{C}, 254 \mathrm{~nm}$ UV detector, retention time $=35.4 \mathrm{~min}$ for $R$ isomer and $39.1 \mathrm{~min}$ for $S$ isomer]. The absolute configuration of $\mathbf{4 c c}$ was assigned by consideration of the stereochemical pathway.

4.4.10. (S)-Triisopropyl[(6-phenethyl-7-octen-1-yl)oxy]silane (4da). The product 4da was purified by flash chromatography on silica gel (0-5\% EtOAc/hexane) (71\% isolated yield). Colorless Oil. IR (neat) 679, 882, 1103, 1462, 2864, $2931 \mathrm{~cm}^{-1} .{ }^{1} \mathrm{H}$ NMR $\left(300 \mathrm{MHz}, \mathrm{CDCl}_{3}\right) \delta 1.01-1.14(\mathrm{~m}, 21 \mathrm{H}), 1.28-1.50(\mathrm{~m}, 6 \mathrm{H})$, $1.52-1.63(\mathrm{~m}, 3 \mathrm{H}), 1.65-1.75(\mathrm{~m}, 1 \mathrm{H}), 1.93-2.05(\mathrm{~m}, 1 \mathrm{H}), 2.51$ (ddd, $J=13.8,10.2,6.6 \mathrm{~Hz}, 1 \mathrm{H}), 2.65$ (ddd, $J=13.8,10.2,5.2$ $\mathrm{Hz}, 1 \mathrm{H}), 3.65$ (t, $J=6.6 \mathrm{~Hz}, 2 \mathrm{H}), 4.96-5.05(\mathrm{~m}, 2 \mathrm{H}), 5.57$ (ddd, $J$ $=17.1,10.4,8.7 \mathrm{~Hz}, 1 \mathrm{H}), 7.15-7.18(\mathrm{~m}, 3 \mathrm{H}), 7.24-7.30(\mathrm{~m}, 2 \mathrm{H})$. ${ }^{13} \mathrm{C} \mathrm{NMR}\left(75.4 \mathrm{MHz}, \mathrm{CDCl}_{3}\right) \delta$

HRMS-EI $(\mathrm{m} / \mathrm{z})$ : $\left[\mathrm{M}_{-} \mathrm{C}_{3} \mathrm{H}_{7}\right]^{+}$calcd for $\mathrm{C}_{22} \mathrm{H}_{37} \mathrm{OSi}$, 345.26137; found, 345.26098. $[\alpha]_{\mathrm{D}}{ }^{25}-3.07\left(c 1.01, \mathrm{CHCl}_{3}\right)$. The ee value $(88 \%$ ee) was determined by chiral HPLC analysis of the alcohol derivative obtained by hydroboration with $9-\mathrm{BBN}-\mathrm{H}$ from 4da
[CHIRALCEL ${ }^{\circledR}$ OD-3 column, $4.6 \mathrm{~mm} \times 250 \mathrm{~mm}$, Daicel Chemical Industries, hexane $/ 2$-propanol $=98: 2,0.5 \mathrm{~mL} / \mathrm{min}, 40$ ${ }^{\circ} \mathrm{C}, 254 \mathrm{~nm}$ UV detector, retention time $=27.2 \mathrm{~min}$ for $R$ isomer and $31.4 \mathrm{~min}$ for $S$ isomer]. The absolute configuration of 4da was assigned by consideration of the stereochemical pathway.

4.4.11. (R)-Triisopropyl[(6-methyl-7-octen-1-yl)oxy]silane (4dd). The product 4dd was purified by flash chromatography on silica gel (hexane) (70\% isolated yield). Colorless Oil. IR (neat) 881, 909, 994, 1103, 1462, 2865, $2930 \mathrm{~cm}^{-1}$. ${ }^{1} \mathrm{H}$ NMR (300 MHz, $\left.\mathrm{CDCl}_{3}\right) \delta 0.97(\mathrm{~d}, J=6.9 \mathrm{~Hz}, 3 \mathrm{H}), 1.01-1.10(\mathrm{~m}, 21 \mathrm{H}), 1.10$ $1.40(\mathrm{~m}, 6 \mathrm{H}), 1.44-1.61(\mathrm{~m} .2 \mathrm{H}), 2.10(\mathrm{~m}, 1 \mathrm{H}), 3.66(\mathrm{t}, J=12.3$ $\mathrm{Hz}, 3 \mathrm{H}), 4.88-4.97(\mathrm{~m}, 2 \mathrm{H}), 5.69$ (ddd, $J=17.710 .5,7.8 \mathrm{~Hz}$, 1H). ${ }^{13} \mathrm{C}$ NMR $\left(75.4 \mathrm{MHz}, \mathrm{CDCl}_{3}\right) \delta$

$32.9,36.6,37.7,63.4,112.3,145.1$. HRMS-EI $(\mathrm{m} / \mathrm{z}):\left[\mathrm{M}-\mathrm{C}_{3} \mathrm{H}_{7}\right]^{+}$ calcd for $\mathrm{C}_{15} \mathrm{H}_{31} \mathrm{OSi}$, 255.21442; found, 25521457. $[\alpha]_{\mathrm{D}}{ }^{26}-4.88$ $\left(c 0.64, \mathrm{CHCl}_{3}\right)$. The ee value $(81 \%$ ee) was determined by chiral HPLC analysis of the $p$-nitrobenzoate derivative obtained by the ozonolysis, reduction with $\mathrm{NaBH}_{4}$, benzoylation ( $p$ nitrobenzoylchloride, DMAP, DCM, rt) followed by desilylation from 4dd [CHIRALCEL ${ }^{\circledR}$ OJ-3 column, $4.6 \mathrm{~mm} \times 250 \mathrm{~mm}$, Daicel Chemical Industries, hexane/2-propanol $=95: 5,0.5$ $\mathrm{mL} / \mathrm{min}, 40{ }^{\circ} \mathrm{C}, 254 \mathrm{~nm} \mathrm{UV}$ detector, retention time $=40.3 \mathrm{~min}$ for $R$ isomer and $42.4 \mathrm{~min}$ for $S$ isomer].The absolute configuration of $\mathbf{4 d d}$ was a assigned by consideration of the stereochemical pathway.

4.4.12. (R)-[(6-Cyclohexyl-7-octen-1-yl)oxy]triisopropylsilane (4de). The product 4de was purified by flash chromatography on silica gel (hexane) followed by GPC $\left(\mathrm{CHCl}_{3}\right)(53 \%$ isolated yield). Colorless Oil. IR (neat) 679, 882, 909, 997, 1103, 1449, $1639,2864,2924 \mathrm{~cm}^{-1} .{ }^{1} \mathrm{H}$ NMR $\left(300 \mathrm{MHz}, \mathrm{CDCl}_{3}\right) \delta 0.83-1.80$ $(\mathrm{m}, 32 \mathrm{H}), 1.06(\mathrm{~s}, 9 \mathrm{H}), 3.66(\mathrm{t}, J=12.3 \mathrm{~Hz}, 2 \mathrm{H}), 4.89(\mathrm{dd}, J=$ $17.1,2.1 \mathrm{~Hz}, 1 \mathrm{H}), 4.97(\mathrm{dd}, J=9.9,2.1 \mathrm{~Hz}, 1 \mathrm{H}), 5.54(\mathrm{dt}, J=$ 17.1, 9.1 Hz, 1H). ${ }^{13} \mathrm{C}$ NMR (75.4 MHz, $\left.\mathrm{CDCl}_{3}\right) \delta 1$

$25.8,26.6,26.6,26.7,27.3,29.6,31.1,31.6,32.9,41.7,50.0$,
$63.5,114.8,141.9$. HRMS-EI $(\mathrm{m} / \mathrm{z}):\left[\mathrm{M}-\mathrm{C}_{3} \mathrm{H}_{7}\right]^{+}$calcd for $\mathrm{C}_{20} \mathrm{H}_{39} \mathrm{OSi}$, 323.27702; found, 323.27741. [ $\left.\alpha\right]_{\mathrm{D}}{ }^{25}-4.08$ (c 1.12, $\left.\mathrm{CHCl}_{3}\right)$. The ee value $(76 \%$ ee) was determined by chiral HPLC analysis of the $p$-nitrobenzoate derivative obtained by the ozonolysis, reduction with $\mathrm{NaBH}_{4}$ followed by benzoylation ( $p$ nitrobenzoylchloride, DMAP, DCM, rt) from 4de [CHIRALCEL $^{\circledR}$ OD-3 column, $4.6 \mathrm{~mm} \times 250 \mathrm{~mm}$, Daicel Chemical Industries, hexane, $0.25 \mathrm{~mL} / \mathrm{min}, 40{ }^{\circ} \mathrm{C}, 254 \mathrm{~nm} \mathrm{UV}$ detector, retention time $=61.0 \mathrm{~min}$ for $R$ isomer and $67.2 \mathrm{~min}$ for $S$ isomer].The absolute configuration of 4 de was a assigned by consideration of the stereochemical pathway.

4.4.13. (S)-6-Phenethyl-7-octen-1-yl Pivalate (4ea). The product 4ea was purified by flash chromatography on silica gel (0-5\% EtOAc/hexane) (73\% isolated yield). Colorless Oil. IR (neat) $698,910,1151,1284,1455,1480,1727,2931 \mathrm{~cm}^{-1} .{ }^{1} \mathrm{H}$ NMR $\left(300 \mathrm{MHz}, \mathrm{CDCl}_{3}\right) \delta 1.19(\mathrm{~s}, 9 \mathrm{H}), 1.24-1.42(\mathrm{~m}, 6 \mathrm{H})$, 1.47-1.74 (m, 4H), 1.93-2.04 (m, 1H), 2.51 (ddd, $J=13.8,10.2$, $6.6 \mathrm{~Hz}, 1 \mathrm{H}), 2.65(\mathrm{ddd}, J=13.8,10.2,5.4 \mathrm{~Hz}, 1 \mathrm{H}), 4.03(\mathrm{t}, J=$ $6.6 \mathrm{~Hz}, 2 \mathrm{H}), 4.96-5.06(\mathrm{~m}, 2 \mathrm{H}), 5.57$ (ddd, $J=17.1,10.2,8.7$ $\mathrm{Hz}, 1 \mathrm{H}), 7.15-7.18,(\mathrm{~m}, 3 \mathrm{H}), 7.24-7.30(\mathrm{~m}, 2 \mathrm{H}) .{ }^{13} \mathrm{C}$ NMR $(75.4$ $\left.\mathrm{MHz}, \mathrm{CDCl}_{3}\right) \delta$

HRMS-EI $(\mathrm{m} / \mathrm{z})$ : $[\mathrm{M}]^{+}$calcd for $\mathrm{C}_{21} \mathrm{H}_{32} \mathrm{O}_{2}, 316.24023$; found, 316.24035. $[\alpha]_{\mathrm{D}}{ }^{25}-4.30\left(c 1.25, \mathrm{CHCl}_{3}\right)$. The ee value $(88 \%$ ee) was determined by chiral HPLC analysis of the $p$-nitrobenzoate derivative obtained by the ozonolysis, reduction with $\mathrm{NaBH}_{4}$ followed by benzoylation ( $p$-nitrobenzoylchloride, DMAP, DCM, rt) from 4ea [CHIRALCEL ${ }^{\circledR}$ OD-3 column, $4.6 \mathrm{~mm} \times 250$ $\mathrm{mm}$, Daicel Chemical Industries, hexane/2-propanol $=95: 5,0.5$ $\mathrm{mL} / \mathrm{min}, 40{ }^{\circ} \mathrm{C}, 254 \mathrm{~nm} \mathrm{UV}$ detector, retention time $=20.5 \mathrm{~min}$ 
for $S$ isomer and $22.5 \mathrm{~min}$ for $R$ isomer]. The absolute configuration of 4ea was assigned by consideration of the stereochemical pathway.

\subsubsection{4.}

(S)-2-\{10-[(tert-Butyldimethylsilyl)oxy]-6vinyldecyl\}isoindoline-1,3-dione (4ff). The product 4 ff was purified by flash chromatography on silica gel $(0-5 \%$ EtOAc/hexane) followed by GPC $\left(\mathrm{CHCl}_{3}\right)(73 \%$ isolated yield $)$. Colorless Oil. IR (neat) 718, 774, 834, 1096, 1254, 1395, 1712, 2857, $2929 \mathrm{~cm}^{-1} .{ }^{1} \mathrm{H}$ NMR $\left(300 \mathrm{MHz}, \mathrm{CDCl}_{3}\right) \delta 0.04(\mathrm{~s}, 6 \mathrm{H})$, 0.89 (s, 9H), 1.16-1.35 (m, 10H), 1.42-1.53 (m, 2H), 1.61-1.71 $(\mathrm{m}, 2 \mathrm{H}), 1.86-1.95(\mathrm{~m}, 1 \mathrm{H}), 3.58(\mathrm{t}, J=6.6 \mathrm{~Hz}, 2 \mathrm{H}), 3.67(\mathrm{t}, J=$ $7.5 \mathrm{~Hz}, 2 \mathrm{H}), 4.91(\mathrm{dd}, J=16.8,2.1 \mathrm{~Hz}, 1 \mathrm{H}), 4.94(\mathrm{dd}, J=10.5$, $2.1 \mathrm{~Hz}, 1 \mathrm{H}), 5.48$ (ddd, $J=16.8,10.5,8.7 \mathrm{~Hz}, 1 \mathrm{H}), 7.70-7.73$ $(\mathrm{m}, 2 \mathrm{H}), 7.83-7.86(\mathrm{~m}, 2 \mathrm{H}) .{ }^{13} \mathrm{C}$ NMR $\left(75.4 \mathrm{MHz}, \mathrm{CDCl}_{3}\right) \delta$ $5.4,18.2,23.2,25.9,26.6,26.9,28.5,32.8,34.7,34.7,38.0,44.0$,
$63.2,114.2,123.2,132.3,133.9,143.3,168.6$. HRMS-ESI $(\mathrm{m} / \mathrm{z})$ : $[\mathrm{M}+\mathrm{Na}]^{+}$calcd for $\mathrm{C}_{26} \mathrm{H}_{41} \mathrm{O}_{3} \mathrm{NNaSi}, 466.27479$; found, 466.27496. $[\alpha]_{\mathrm{D}}{ }^{25}-0.41\left(c 1.05, \mathrm{CHCl}_{3}\right)$. The ee value $(88 \%$ ee $)$ was determined by chiral HPLC analysis of the $p$-nitrobenzoate derivative obtained by the ozonolysis, reduction with $\mathrm{NaBH}_{4}$ followed by benzoylation ( $p$-nitrobenzoylchloride, DMAP, DCM, rt) from 4ff [CHIRALCEL ${ }^{\circledR}$ AD-H column, $4.6 \mathrm{~mm} \times 250$ $\mathrm{mm}$, Daicel Chemical Industries, hexane/2-propanol $=97: 3,0.5$ $\mathrm{mL} / \mathrm{min}, 40{ }^{\circ} \mathrm{C}, 254 \mathrm{~nm} \mathrm{UV}$ detector, retention time $=32.2 \mathrm{~min}$ for $R$ isomer and $35.1 \mathrm{~min}$ for $S$ isomer]. The absolute configuration of $\mathbf{4 f f}$ was assigned by consideration of the stereochemical pathway.

4.4.15. (S)-2-(10-Chloro-6-vinyldecyl)isoindoline-1,3-dione (4fc). The product $\mathbf{4 f c}$ was purified by flash chromatography on silica gel (0-5\% EtOAc/hexane) (72\% isolated yield). Colorless Oil. IR (neat) 717, 911, 1394, 1708, 1773, $2932 \mathrm{~cm}^{-1} .{ }^{1} \mathrm{H}$ NMR $\left(300 \mathrm{MHz}, \mathrm{CDCl}_{3}\right) \delta 1.18-1.47(\mathrm{~m}, 10 \mathrm{H}), 1.62-1.77(\mathrm{~m}, 4 \mathrm{H})$, $1.86-1.97(\mathrm{~m}, 1 \mathrm{H}), 3.52(\mathrm{t}, J=6.6 \mathrm{~Hz}, 2 \mathrm{H}), 3.67(\mathrm{t}, J=7.2 \mathrm{~Hz}$, 2H), 4.93 (dd, $J=16.8,1.8 \mathrm{~Hz}, 1 \mathrm{H}), 4.95$ (dd, $J=10.2,1.8 \mathrm{~Hz}$, 1H) 5.48 (ddd, $J=16.8,10.2,9.0 \mathrm{~Hz}, 1 \mathrm{H}), 7.69-7.74(\mathrm{~m}, 2 \mathrm{H})$, 7.82-7.87 (m, 2H). ${ }^{13} \mathrm{C}$ NMR (75.4 MHz, $\left.\mathrm{CDCl}_{3}\right) \delta 24.4,26.6$, $26.8,28.4,32.6,34.1,34.7,37.9,43.8,45.0,114.6,123.2,132.2$
$133.9,143.0,168.6$. HRMS-ESI $(\mathrm{m} / \mathrm{z}):[\mathrm{M}+\mathrm{Na}]^{+}$calcd for $\mathrm{C}_{20} \mathrm{H}_{26} \mathrm{O}_{2} \mathrm{NClNa}$, 370.15443; found, 370.15468. [ $\left.\alpha\right]_{\mathrm{D}}{ }^{25}+0.53(c$ $\left.1.07, \mathrm{CHCl}_{3}\right)$. The ee value $(90 \%$ ee) was determined by chiral HPLC analysis of the $p$-nitrobenzoate derivative obtained by the ozonolysis, reduction with $\mathrm{NaBH}_{4}$ followed by benzoylation ( $p$ nitrobenzoylchloride, DMAP, DCM, rt) from 4fc [CHIRALCEL ${ }^{\circledR}$ AD-H column, $4.6 \mathrm{~mm} \times 250 \mathrm{~mm}$, Daicel Chemical Industries, hexane/2-propanol $=97: 3,0.5 \mathrm{~mL} / \mathrm{min}, 40{ }^{\circ} \mathrm{C}, 254 \mathrm{~nm} \mathrm{UV}$ detector, retention time $=166.9 \mathrm{~min}$ for $R$ isomer and $179.2 \mathrm{~min}$ for $S$ isomer]. The absolute configuration of $\mathbf{4 f c}$ was assigned by consideration of the stereochemical pathway.

4.4.16. (R)-Dimethylphenyl(1-undecen-3-yl)silane (4hg). The product 4 hg was purified by flash chromatography on silica gel (hexane) (77\% isolated yield). Colorless Oil. IR (neat) 698, 811, $1113,1248,1428,1626,2924 \mathrm{~cm}^{-1} .{ }^{1} \mathrm{H}$ NMR $\left(300 \mathrm{MHz}, \mathrm{CDCl}_{3}\right)$ $\delta 0.25(\mathrm{~s}, 3 \mathrm{H}), 0.26(\mathrm{~s}, 3 \mathrm{H}), 0.86(\mathrm{t}, J=6.6 \mathrm{~Hz}, 3 \mathrm{H}), 1.13-1.37$ $(\mathrm{m}, 14 \mathrm{H}), 1.62-1.76(\mathrm{~m}, 1 \mathrm{H}), 4.77-4.83(\mathrm{~m}, 1 \mathrm{H}), 4.88(\mathrm{dd}, J=$ $10.2,2.1 \mathrm{~Hz}, 1 \mathrm{H}), 5.58(\mathrm{dt}, J=17.1,10.2 \mathrm{~Hz}, 1 \mathrm{H}), 7.32-7.36(\mathrm{~m}$, $3 \mathrm{H}), 7.48-7.51(\mathrm{~m}, 2 \mathrm{H}) .{ }^{13} \mathrm{C} \mathrm{NMR}\left(75.4 \mathrm{MHz}, \mathrm{CDCl}_{3}\right) \delta$

HRMS-EI $(\mathrm{m} / \mathrm{z}):[\mathrm{M}]^{+}$calcd for $\mathrm{C}_{19} \mathrm{H}_{32} \mathrm{Si}, 288.22733$; found, 288.22732. $[\alpha]_{\mathrm{D}}{ }^{27}-7.05$ (c 1.23, $\mathrm{CHCl}_{3}$ ). HPLC analysis [CHIRALCEL ${ }^{\circledR} \mathrm{OJ}-3$ column, $4.6 \mathrm{~mm} \times$ $250 \mathrm{~mm} / \mathrm{OJ}-3$ column, $4.6 \mathrm{~mm} \times 250 \mathrm{~mm} / \mathrm{OJ}-\mathrm{H}$ column, $4.6 \mathrm{~mm}$ $\times 250 \mathrm{~mm}$, Daicel Chemical Industries, hexane, $0.25 \mathrm{~mL} / \mathrm{min}, 40$ ${ }^{\circ} \mathrm{C}, 254 \mathrm{~nm} \mathrm{UV}$ detector, retention time $=55.0 \mathrm{~min}$ for $S$ isomer and $56.4 \mathrm{~min}$ for $R$ isomer] revealed that the enantiomeric excess of 4 hg was $91 \%$.

Derivatization of $\mathbf{4 h g}$ (Scheme $4 \mathrm{~b}$ ). $p$-Toluenesulfonyl hydrazide (186.2 $\mathrm{mg}, 1.0 \mathrm{mmol}$ ) was placed in a screw-top test tube. Allylsilane 4hg (28.9 mg, $0.1 \mathrm{mmol}), 1$,4-dioxane $(1 \mathrm{~mL})$ and triethylamine $(0.14 \mathrm{~mL}, 1.0 \mathrm{mmol})$ were sequentially added to the test tube at $25{ }^{\circ} \mathrm{C}$. The resulting mixture was stirred at reflux for $24 \mathrm{~h}$ (monitored by TLC). After the mixture was cooled to 25 ${ }^{\circ} \mathrm{C}$, water was added. The aqueous layer was extracted with hexane (three times). The combined organic layer was washed with water and brine, and then was dried and concentrated. The crude product was used in the next step without further purification. A vial containing the crude material of 4hga (29.1 $\mathrm{mg}, 0.1 \mathrm{mmol})$ was filled with argon. $\mathrm{CH}_{2} \mathrm{Cl}_{2}(1.0 \mathrm{~mL})$ and $\mathrm{HBF}_{4} \bullet \mathrm{OEt}_{2}(0.23 \mathrm{~mL}, 0.28 \mathrm{mmol})$ were sequentially added at 25 ${ }^{\circ} \mathrm{C}$. After $1.5 \mathrm{~h}$ stirring at $25{ }^{\circ} \mathrm{C}$, the mixture was quenched with water. The aqueous layer was extracted with hexane (three times). The combined organic layer was washed with water and brine, and then was dried and concentrated. The crude product was used in the next step without further purification. The fluorinated compound $4 \mathbf{h g b}$ ( $23.2 \mathrm{mg}, 0.1 \mathrm{mmol}$ ) was placed in a screw-top test tube. THF $(0.4 \mathrm{~mL}), \mathrm{MeOH}(0.4 \mathrm{~mL}), \mathrm{KF}(23.2 \mathrm{mg}, 0.4$ $\mathrm{mmol}$ ), $\mathrm{KHCO}_{3}(100.2 \mathrm{mg}, 1 \mathrm{mmol}), 30 \% \mathrm{H}_{2} \mathrm{O}_{2}$ aq $(113.4 \mathrm{mg}, 1$ mmol) were sequentially added at $25^{\circ} \mathrm{C}$. After being stirred at 40 ${ }^{\circ} \mathrm{C}$ for $24 \mathrm{~h}$, the mixture was quenched with $\mathrm{Na}_{2} \mathrm{~S}_{2} \mathrm{O}_{3}$ aq. The aqueous layer was extracted with ethyl acetate (three times). The combined organic layer was washed with water and brine, and then was dried and concentrated. The crude product was purified by flash column chromatography (5-20\% EtOAc/hexane) to yield $(S)$-undecan-3-ol (4hgc) as a colorless oil (10.2 mg, 0.06 mmol, $59 \%$ in 3 steps $)[\alpha]_{\mathrm{D}}{ }^{25}+4.38\left(c 0.51, \mathrm{CHCl}_{3}\right) .\left\{\mathrm{lit}^{22},(S)\right.$ isomer, $84 \%$ ee, $\left.[\alpha]_{\mathrm{D}}{ }^{20}+5.2\left(c 1, \mathrm{CHCl}_{3}\right)\right\}$.

4.4.17.

(R)-[8-(1,3-Dioxan-2-yl)-1-octen-3yl]dimethylphenylsilane $(4 \mathrm{cg})$. The product $4 \mathrm{cg}$ was purified by flash chromatography on silica gel $(0-5 \%$ EtOAc/hexane $)$ followed by GPC $\left(\mathrm{CHCl}_{3}\right)(66 \%$ isolated yield). Colorless Oil. IR (neat) $699,996,1144,1246,1625,2850,2953 \mathrm{~cm}^{-1} .{ }^{1} \mathrm{H}$ NMR $\left(300 \mathrm{MHz}, \mathrm{CDCl}_{3}\right) \delta 0.25(\mathrm{~s}, 3 \mathrm{H}), 0.26(\mathrm{~s}, 3 \mathrm{H}), 1.13-1.41(\mathrm{~m}$, $9 \mathrm{H}), 1.50-1.57(\mathrm{~m}, 2 \mathrm{H}), 1.62-1.75(\mathrm{~m}, 1 \mathrm{H}), 2.00-2.13(\mathrm{~m}, 1 \mathrm{H})$, $3.74(\mathrm{dt}, J=12.0,2.4 \mathrm{~Hz}, 2 \mathrm{H}), 4.06-4.11(\mathrm{~m}, 2 \mathrm{H}), 4.47(\mathrm{t}, J=$ $5.1 \mathrm{~Hz}, 1 \mathrm{H}), 4.75-4.82(\mathrm{~m}, 1 \mathrm{H}), 4.87(\mathrm{dd}, J=10.2,1.8 \mathrm{~Hz}, 1 \mathrm{H})$, $5.56(\mathrm{dt}, J=17.1,10.2 \mathrm{~Hz}, 1 \mathrm{H}), 7.32-7.37(\mathrm{~m}, 3 \mathrm{H}), 7.46-7.50$ $(\mathrm{m}, 2 \mathrm{H}) .{ }^{13} \mathrm{C}$ NMR $\left(75.4 \mathrm{MHz}, \mathrm{CDCl}_{3}\right) \delta$

$28.2,29.0,29.1,34.3,35.1,66.9,102.4,112.5,127.7,128.9$,
$134.1,138.0,139.9$. HRMS-ESI $(\mathrm{m} / \mathrm{z}):[\mathrm{M}+\mathrm{Na}]^{+}$calcd for
$\mathrm{C}_{20} \mathrm{H}_{32} \mathrm{O}_{2} \mathrm{NaSi}, 355.20638$; found, 355.20672. $[\alpha]_{\mathrm{D}}{ }^{26}-5.64(\mathrm{c}$
$\left.1.17, \mathrm{CHCl}_{3}\right)$. HPLC analysis [CHIRALCEL ${ }^{\mathbb{}} \mathrm{OD}-3$ column, 4.6
$\mathrm{~mm} \times 250 \mathrm{~mm}$, Daicel Chemical Industries, hexane/2-propanol =
$99.9: 0.1,0.5 \mathrm{~mL} / \mathrm{min}, 40{ }^{\circ} \mathrm{C}, 254 \mathrm{~nm} \mathrm{UV}$ detector, retention time
$=17.4 \mathrm{~min}$ for $S$ isomer and $18.1 \mathrm{~min}$ for $R$ isomer] revealed that
the enantiomeric excess of $\mathbf{4 c g}$ was $91 \%$. The absolute
configuration of $\mathbf{4 c g}$ was assigned by consideration of the
stereochemical pathway.

4.4.18. (R)-6-(Dimethylphenylsilyl)-7-octen-1-yl Pivalate (4eg). The product 4 eg was purified by flash chromatography on silica gel (0-5\% EtOAc/hexane) (52\% isolated yield). Colorless Oil. IR (neat) $600,812,1152,1284,1626,1727,2932 \mathrm{~cm}^{-1} .{ }^{1} \mathrm{H}$ NMR (300 MHz, $\left.\mathrm{CDCl}_{3}\right) \delta 0.25(\mathrm{~s}, 3 \mathrm{H}), 0.26(\mathrm{~s}, 3 \mathrm{H}), 1.18(\mathrm{~s}$, $9 \mathrm{H}), 1.10-1.50(\mathrm{~m}, 6 \mathrm{H}), 1.52-1.60(\mathrm{~m}, 2 \mathrm{H}), 1.69-1.76(\mathrm{~m}, 1 \mathrm{H})$, $4.00(\mathrm{t}, J=6.6 \mathrm{~Hz}, 2 \mathrm{H}), 4.78-4.83(\mathrm{~m}, 1 \mathrm{H}), 4.88(\mathrm{dd}, J=10.2$, $1.8 \mathrm{~Hz}, 1 \mathrm{H}), 5.57$ (dt, $J=17.1,10.2 \mathrm{~Hz}, 1 \mathrm{H}), 7.34-7.36(\mathrm{~m}, 3 \mathrm{H})$, 7.47-7.51 (m, 2H). ${ }^{13} \mathrm{C}$ NMR (75.4 MHz, $\left.\mathrm{CDCl}_{3}\right) \delta$

HRMS-ESI $(\mathrm{m} / \mathrm{z}):[\mathrm{M}+\mathrm{Na}]^{+}$calcd for 
$\mathrm{C}_{21} \mathrm{H}_{34} \mathrm{O}_{2} \mathrm{NaSi}$, 369.22203; found, 369.22208. [ $\left.\alpha\right]_{\mathrm{D}}{ }^{25}-8.09(c$ $1.27, \mathrm{CHCl}_{3}$ ). HPLC analysis [CHIRALCEL ${ }^{\circledR}$ OD-3 column, 4.6 $\mathrm{mm} \times 250 \mathrm{~mm}$, Daicel Chemical Industries, hexane, 0.25 $\mathrm{mL} / \mathrm{min}, 40{ }^{\circ} \mathrm{C}, 254 \mathrm{~nm}$ UV detector, retention time $=41.1 \mathrm{~min}$ for $S$ isomer and $43.0 \mathrm{~min}$ for $R$ isomer] revealed that the enantiomeric excess of $\mathbf{4 e g}$ was $87 \%$. The absolute configuration of $4 \mathbf{e g}$ was assigned by consideration of the stereochemical pathway.

4.4.19.

(R)-2-[6-(Dimethylphenylsilyl)-7-octen-1yl]isoindoline-1,3-dione (4fg). The product $\mathbf{4 f g}$ was purified by flash chromatography on silica gel $(0-5 \%$ EtOAc/hexane) $(85 \%$ isolated yield). Colorless Oil. IR (neat) 717, 1394, 1624, 1708, $1773,2931 \mathrm{~cm}^{-1} .{ }^{1} \mathrm{H}$ NMR (300 MHz, $\left.\mathrm{CDCl}_{3}\right) \delta 0.24(\mathrm{~s}, 3 \mathrm{H})$, $0.25(\mathrm{~s}, 3 \mathrm{H}), 1.16-1.43(\mathrm{~m}, 6 \mathrm{H}), 1.54-1.74(\mathrm{~m}, 3 \mathrm{H}), 3.63(\mathrm{t}, J=$ $7.2 \mathrm{~Hz}, 2 \mathrm{H}), 4.75-4.81(\mathrm{~m}, 1 \mathrm{H}), 4.86(\mathrm{dd}, J=10.2,1.8 \mathrm{~Hz}, 1 \mathrm{H})$, $5.55(\mathrm{dt}, J=17.1,10.2 \mathrm{~Hz}, 1 \mathrm{H}), 7.31-7.34(\mathrm{~m}, 3 \mathrm{H}), 7.46-7.49$ $(\mathrm{m}, 2 \mathrm{H}), 7.69-7.73(\mathrm{~m}, 2 \mathrm{H}), 7.81-7.85(\mathrm{~m}, 2 \mathrm{H}) .{ }^{13} \mathrm{C}$ NMR $(75.4$ $\left.\mathrm{MHz}, \mathrm{CDCl}_{3}\right) \delta$

HRMS-ESI $(\mathrm{m} / \mathrm{z}):[\mathrm{M}+\mathrm{Na}]^{+}$calcd for $\mathrm{C}_{24} \mathrm{H}_{29} \mathrm{O}_{2} \mathrm{NNaSi}$, 414.18598; found, 414.18631. $[\alpha]_{\mathrm{D}}{ }^{27}+4.99\left(c \mathrm{0.75}, \mathrm{CHCl}_{3}\right)$. HPLC analysis [CHIRALCEL ${ }^{\circledR}$ OD-3 column, $4.6 \mathrm{~mm} \times 250$ $\mathrm{mm}$, Daicel Chemical Industries, hexane/2-propanol $=99.5: 0.5$, $0.5 \mathrm{~mL} / \mathrm{min}, 40{ }^{\circ} \mathrm{C}, 254 \mathrm{~nm}$ UV detector, retention time $=31.6$ min for $S$ isomer and $33.4 \mathrm{~min}$ for $R$ isomer] revealed that the enantiomeric excess of $\mathbf{4 f g}$ was $\mathbf{9 0 \%}$. The absolute configuration of $\mathbf{4 f g}$ was assigned by consideration of the stereochemical pathway.

4.4.20. (R)-(9-Chloro-1-nonen-3-yl)dimethylphenylsilane (4ig). The product 4ig was purified by flash chromatography on silica gel (hexane) ( $88 \%$ isolated yield). Colorless Oil. IR (neat) 699, 894, 1122, 1248, 1427, 1625, 2855, $2928 \mathrm{~cm}^{-1} .{ }^{1} \mathrm{H}$ NMR $\left(300 \mathrm{MHz}, \mathrm{CDCl}_{3}\right) \delta 0.25(\mathrm{~s}, 3 \mathrm{H}), 0.26(\mathrm{~s}, 3 \mathrm{H}), 1.13-1.41(\mathrm{~m}$, $8 \mathrm{H}), 1.66-1.76(\mathrm{~m}, 3 \mathrm{H}), 3.49(\mathrm{t}, J=6.9 \mathrm{~Hz}, 2 \mathrm{H}), 4.78-4.84(\mathrm{~m}$, $1 \mathrm{H}), 4.89(\mathrm{dd}, J=9.9,1.8 \mathrm{~Hz}, 1 \mathrm{H}), 5.58(\mathrm{dt}, J=17.1,9.9 \mathrm{~Hz}$, $1 \mathrm{H}), 7.33-7.36(\mathrm{~m}, 3 \mathrm{H}), 7.46-7.51(\mathrm{~m}, 2 \mathrm{H}) .{ }^{13} \mathrm{C}$ NMR $(75.4$ $\left.\mathrm{MHz}, \mathrm{CDCl}_{3}\right) \delta$

HRMS-FI $(\mathrm{m} / \mathrm{z})$ : $[\mathrm{M}]^{+}$calcd for $\mathrm{C}_{17} \mathrm{H}_{27} \mathrm{ClSi}$, 294.15705; found, 294.15724. $[\alpha]_{\mathrm{D}}{ }^{25}$ -10.36 (c 1.30, $\mathrm{CHCl}_{3}$ ). HPLC analysis [CHIRALCEL ${ }^{\circledR}$ OJ-3 column, $4.6 \mathrm{~mm} \times 250 \mathrm{~mm} / \mathrm{OJ}-\mathrm{H}$ column, $4.6 \mathrm{~mm} \times 250 \mathrm{~mm}$, Daicel Chemical Industries, hexane, $0.25 \mathrm{~mL} / \mathrm{min}, 40{ }^{\circ} \mathrm{C}, 254 \mathrm{~nm}$ UV detector, retention time $=36.9 \mathrm{~min}$ for $S$ isomer and $38.1 \mathrm{~min}$ for $R$ isomer] revealed that the enantiomeric excess of 4 ig was $91 \%$. The absolute configuration of 4 ig was assigned by consideration of the stereochemical pathway.

4.4.21. (S)-1,2-Dimethoxy-4-(4-methyl-4-phenethyl-5-hexen-1yl)benzene (6aa). The product $(S)$-6aa was purified by flash chromatography on silica gel (0-2\% EtOAc/hexane) followed by GPC $\left(\mathrm{CHCl}_{3}\right)(65 \%$ isolated yield). Colorless Oil. IR (neat) 698, 1030, 1236, 1260, 1515, $2935 \mathrm{~cm}^{-1} .{ }^{1} \mathrm{H}$ NMR $\left(300 \mathrm{MHz}, \mathrm{CDCl}_{3}\right)$ $\delta 1.03(\mathrm{~s}, 3 \mathrm{H}), 1.35-1.40(\mathrm{~m}, 2 \mathrm{H}), 1.55-1.65(\mathrm{~m}, 4 \mathrm{H}), 2.45-2.55$ $(\mathrm{m}, 4 \mathrm{H}), 3.85(\mathrm{~s}, 3 \mathrm{H}), 3.87(\mathrm{~s}, 3 \mathrm{H}), 4.94(\mathrm{~d}, J=17.4 \mathrm{~Hz}, 1 \mathrm{H})$, $5.04(\mathrm{~d}, J=10.8 \mathrm{~Hz}, 1 \mathrm{H}), 5.74(\mathrm{dd}, J=17.4,10.8 \mathrm{~Hz}, 1 \mathrm{H}), 6.70$ $6.72(\mathrm{~m}, 2 \mathrm{H}), 6.79(\mathrm{~m}, 1 \mathrm{H}), 7.13-7.18(\mathrm{~m}, 3 \mathrm{H}), 7.24-7.29(\mathrm{~m}$, $2 \mathrm{H}) .{ }^{13} \mathrm{C} \mathrm{NMR}\left(100.5 \mathrm{MHz}, \mathrm{CDCl}_{3}\right) \delta 2$

HRMS-EI $(\mathrm{m} / \mathrm{z}):[\mathrm{M}]^{+}$ calcd for $\mathrm{C}_{23} \mathrm{H}_{30} \mathrm{O}_{2}, 338.22458$; found, 338.22391. $[\alpha]_{\mathrm{D}}^{23}+5.81(c$ $1.10, \mathrm{CHCl}_{3}$ ). HPLC analysis [CHIRALCEL ${ }^{\circledR}$ OD-3 column, 4.6 $\mathrm{mm} \times 250 \mathrm{~mm}$, Daicel Chemical Industries, hexane/2-propanol $=$ 99.5:0.5, $0.5 \mathrm{~mL} / \mathrm{min}, 40{ }^{\circ} \mathrm{C}, 220 \mathrm{~nm}$ UV detector, retention time $=106.7 \mathrm{~min}$ for $R$ isomer and $112.5 \mathrm{~min}$ for $S$ isomer] revealed that the enantiomeric excess of $\mathbf{6 a a}$ was $81 \%$ ee. The absolute configuration of 6aa was assigned by consideration of the stereochemical pathway.

4.4.22. (S)-2-(6-Methyl-6-phenethyl-7-octen-1-yl)-1,3-dioxane (6ca). The product $\mathbf{6 c a}$ was purified by flash chromatography on silica gel (0-2\% EtOAc/hexane) (79\% isolated yield). Colorless Oil. IR (neat) 698, 909, 996, 1143, 2849, $2929 \mathrm{~cm}^{-1} .{ }^{1} \mathrm{H}$ NMR $\left(300 \mathrm{MHz}, \quad \mathrm{CDCl}_{3}\right) \quad \delta \quad \mathrm{s} \quad$ $\mathrm{m}, 8 \mathrm{H}, 1.54-1.64(\mathrm{~m}, 5 \mathrm{H}), 2.08(\mathrm{~m}, 1 \mathrm{H}), 2.46-2.52$ $(\mathrm{m}, 2 \mathrm{H}), 3.76(\mathrm{dt}, J=12.0,2.4 \mathrm{~Hz}, 2 \mathrm{H}), 4.08-4.13(\mathrm{~m}, 2 \mathrm{H}), 4.50$ $(\mathrm{t}, J=5.1 \mathrm{~Hz}, 1 \mathrm{H}), 4.93(\mathrm{dd}, J=17.4,1.5 \mathrm{~Hz}, 1 \mathrm{H}), 5.02(\mathrm{dd}, J=$ $10.8,1.5 \mathrm{~Hz}, 1 \mathrm{H}), 5.74(\mathrm{dd}, J=17.4,10.8 \mathrm{~Hz}, 1 \mathrm{H}), 7.15-7.19$ $(\mathrm{m}, 3 \mathrm{H}), 7.25-7.30(\mathrm{~m}, 2 \mathrm{H}) .{ }^{13} \mathrm{C}$ NMR $\left(100.5 \mathrm{MHz}, \mathrm{CDCl}_{3}\right)$ $\delta 22623.9,24.0,25.8,30.3,30.7,35.2,39.6,40.7,43.0,66.9$
$102.4,111.8,125.5,128.3$ (2C), 143.4, 147.1. HRMS-EI $(\mathrm{m} / \mathrm{z})$ : $[\mathrm{M}]^{+}$calcd for $\mathrm{C}_{21} \mathrm{H}_{32} \mathrm{O}_{2}, 316.24023$; found, 316.24002. $[\alpha]_{\mathrm{D}}{ }^{26}$ $+2.06\left(c 1.08, \mathrm{CHCl}_{3}\right)$. The ee value $(90 \%$ ee) was determined by chiral HPLC analysis of the aldehyde derivative obtained by the ozonolysis followed by reduction with $\mathrm{Me}_{2} \mathrm{~S}$ from 6ca [CHIRALCEL $^{\circledR}$ OD-3 column, $4.6 \mathrm{~mm} \times 250$ mm/CHIRALCEL ${ }^{\circledR} \quad$ OD-H column, $4.6 \mathrm{~mm} \times 250$ $\mathrm{mm} / \mathrm{CHIRALCEL}^{\circledR}$ OD-H column, $4.6 \mathrm{~mm} \times 250 \mathrm{~mm}$, Daicel Chemical Industries, hexane $/ 2$-propanol $=96: 4,0.7 \mathrm{~mL} / \mathrm{min}, 40$ ${ }^{\circ} \mathrm{C}, 220 \mathrm{~nm}$ UV detector, retention time $=54.1 \mathrm{~min}$ for $R$ isomer and $55.7 \mathrm{~min}$ for $S$ isomer]. The absolute configuration of $\mathbf{6 c a}$ was assigned by consideration of the stereochemical pathway.

4.4.23. (S)-Triisopropyl[(6-methyl-6-phenethyl-7-octen-1yl)oxy]silane (6da). The product 6da was purified by flash chromatography on silica gel $(0-1 \%$ EtOAc/hexane) $(85 \%$ isolated yield). Colorless Oil. IR (neat) 679, 910, 1106, 1463, 2864, $2938 \mathrm{~cm}^{-1} .{ }^{1} \mathrm{H}$ NMR $\left(300 \mathrm{MHz}, \mathrm{CDCl}_{3}\right) \delta 1.05-1.12,(\mathrm{~m}$, 24H), 1.21-1.32 (m, 6H), 1.50-1.64 (m, 4H), 2.47-2.53 (m, 2H), $3.66(\mathrm{t}, J=6.6 \mathrm{~Hz}, 2 \mathrm{H}), 4.94(\mathrm{dd}, J=17.4,1.5 \mathrm{~Hz}, 1 \mathrm{H}), 5.04(\mathrm{dd}$, $J=11.1,1.5 \mathrm{~Hz}, 1 \mathrm{H}), 5.75$ (dd, $J=17.4,11.1 \mathrm{~Hz}, 1 \mathrm{H}), 7.15-7.17$ (m, 3H), 7.24-7.29 (m, 2H). $\left.{ }^{13} \mathrm{C} \mathrm{NMR} \mathrm{(100.5} \mathrm{MHz,} \mathrm{CDCl}_{3}\right) \delta$ $12.0,18.0,22.6,23.9,26.6,30.7,33.0,39.6,40.9,43.0,63.4$
$111.8,125.5,128.3$ $[\mathrm{M}+\mathrm{H}]^{+}$calcd for $\mathrm{C}_{26} \mathrm{H}_{47} \mathrm{OSi}$, 403.33907; found, 403.33838 . $[\alpha]_{\mathrm{D}}{ }^{27}+6.31\left(c 0.92, \mathrm{CHCl}_{3}\right)$. The ee value $(83 \%$ ee) was determined by chiral HPLC analysis of the aldehyde derivative obtained by the ozonolysis, reduction with $\mathrm{Me}_{2} \mathrm{~S}$ from 6da [CHIRALCEL $^{\circledR} \quad$ OD-3 column, $4.6 \mathrm{~mm} \times 250$ mm/CHIRALCEL ${ }^{\circledR} \quad$ OD-H column, $4.6 \mathrm{~mm} \times 250$ $\mathrm{mm} / \mathrm{CHIRALCEL}^{\circledR}$ OD-H column, $4.6 \mathrm{~mm} \times 250 \mathrm{~mm}$, Daicel Chemical Industries, hexane/2-propanol $=98: 2,0.3 \mathrm{~mL} / \mathrm{min}, 40$ ${ }^{\circ} \mathrm{C}, 220 \mathrm{~nm} \mathrm{UV}$ detector, retention time $=17.9 \mathrm{~min}$ for $R$ isomer and 18.6 min for $S$ isomer]. The absolute configuration of $6 \mathbf{d a}$ was assigned by consideration of the stereochemical pathway.

4.4.24. (S)-6-Methyl-6-phenethyl-7-octen-1-yl Pivalate (6ea). The product 6ea was purified by flash chromatography on silica gel (0-2\% EtOAc/hexane) (66\% isolated yield). Colorless Oil. IR (neat) 698, 1284, 1151, 1727, 2862, $2935 \mathrm{~cm}^{-1} .{ }^{1} \mathrm{H}$ NMR $(300$ $\left.\mathrm{MHz}, \mathrm{CDCl}_{3}\right) \delta 1.03(\mathrm{~s}, 3 \mathrm{H}), 1.19(\mathrm{~s}, 9 \mathrm{H}), 1.29-1.32(\mathrm{~m}, 6 \mathrm{H})$, $1.52-1.64(\mathrm{~m}, 4 \mathrm{H}), 2.47-2.53(\mathrm{~m}, 2 \mathrm{H}), 4.04(\mathrm{t}, J=6.6 \mathrm{~Hz}, 2 \mathrm{H})$, $4.95(\mathrm{~d}, J=17.4 \mathrm{~Hz}, 1 \mathrm{H}), 5.04(\mathrm{~d}, J=11.1 \mathrm{~Hz}, 1 \mathrm{H}), 5.75(\mathrm{dd}, J=$ 17.4, $11.1 \mathrm{~Hz}, 1 \mathrm{H}), 7.15-7.19(\mathrm{~m}, 3 \mathrm{H}), 7.25-7.30(\mathrm{~m}, 2 \mathrm{H}) .{ }^{13} \mathrm{C}$ NMR $\left(100.5 \mathrm{MHz}, \mathrm{CDCl}_{3}\right) \delta$

$38.7,39.6,40.9,43.0,64.4,112.0,125.6,128.3(2 \mathrm{C}), 143.3$,
$146.9,178.7$. HRMS-EI $(\mathrm{m} / \mathrm{z}):[\mathrm{M}]^{+}$calcd for $\mathrm{C}_{22} \mathrm{H}_{34} \mathrm{O}_{2}$, 330.25588; found, 330.25630. $[\alpha]_{\mathrm{D}}^{25}+7.36\left(c 0.58, \mathrm{CHCl}_{3}\right)$. The ee value $(81 \%$ ee) was determined by chiral HPLC analysis of the aldehyde derivative obtained by the ozonolysis followed by reduction with $\mathrm{Me}_{2} \mathrm{~S}$ from 6ea [CHIRALCEL ${ }^{\circledR}$ OD-3 column, 4.6 $\mathrm{mm} \times 250 \mathrm{~mm} /$ CHIRALCEL $^{\circledR}$ OD-H column, $4.6 \mathrm{~mm} \times 250$ $\mathrm{mm} / \mathrm{CHIRALCEL}^{\circledR}$ OD-H column, $4.6 \mathrm{~mm} \times 250 \mathrm{~mm}$, Daicel 
Chemical Industries, hexane $/ 2$-propanol $=96: 4,0.7 \mathrm{~mL} / \mathrm{min}$, $40{ }^{\circ} \mathrm{C}, 220 \mathrm{~nm} \mathrm{UV}$ detector, retention time $=29.7 \mathrm{~min}$ for $R$ isomer and $30.6 \mathrm{~min}$ for $S$ isomer] The absolute configuration of 6ea was assigned by consideration of the stereochemical pathway.

4.4.25. (S)-(9-Chloro-3-methyl-3-vinylnonyl)benzene (6ia). The product 6 ia was purified by flash chromatography on silica gel (hexane) followed by GPC $\left(\mathrm{CHCl}_{3}\right)(80 \%$ isolated yield). Colorless Oil. IR (neat) 696, 909, 1453, 1495, 2858, $2930 \mathrm{~cm}^{-1}$. ${ }^{1} \mathrm{H}$ NMR $\left(300 \mathrm{MHz}, \mathrm{CDCl}_{3}\right) \delta 1.03(\mathrm{~s}, 3 \mathrm{H}), 1.26-1.48(\mathrm{~m}, 6 \mathrm{H})$, $1.52-1.61(\mathrm{~m}, 4 \mathrm{H}), 1.72-1.79(\mathrm{~m}, 2 \mathrm{H}), 2.47-2.53(\mathrm{~m}, 2 \mathrm{H}), 3.53$ (t, $J=6.6 \mathrm{~Hz}, 2 \mathrm{H}), 4.95$ (dd, $J=17.4,1.5 \mathrm{~Hz}, 1 \mathrm{H}), 5.04$ (dd, $J=$ 11.1, $1.5 \mathrm{~Hz}, 1 \mathrm{H}), 5.75$ (dd, $J=17.4,11.1 \mathrm{~Hz}, 1 \mathrm{H}), 7.15-7.20$ $(\mathrm{m}, 3 \mathrm{H}), 7.25-7.30(\mathrm{~m}, 2 \mathrm{H}) .{ }^{13} \mathrm{C}$ NMR $\left(100.5 \mathrm{MHz}, \mathrm{CDCl}_{3}\right) \delta$ $22.5,23.9,26.9,29.7,30.7,32.6,39.6,40.8,43.0,45.2,111.9$,
$125.5,128.3(2 \mathrm{C}), 143.3,147.0$. HRMS-EI $(\mathrm{m} / \mathrm{z}):[\mathrm{M}]^{+}$calcd for $\mathrm{C}_{18} \mathrm{H}_{27} \mathrm{Cl}$, 278.1803; found, 278.18100. $[\alpha]_{\mathrm{D}}{ }^{26}+6.49$ (c 0.30, $\left.\mathrm{CHCl}_{3}\right)$. The ee value ( $86 \%$ ee) was determined by chiral HPLC analysis of the aldehyde derivative obtained by the ozonolysis followed by reduction with $\mathrm{Me}_{2} \mathrm{~S}$ from 6ia [CHIRALCEL ${ }^{\circledR}$ OD-3 column, $4.6 \mathrm{~mm} \times 250 \mathrm{~mm} / \mathrm{CHIRALCEL}^{\circledR}$ OD-H column, 4.6 $\mathrm{mm} \times 250 \mathrm{~mm} /$ CHIRALCEL $^{\circledR}$ OD-H column, $4.6 \mathrm{~mm} \times 250$ $\mathrm{mm}$, Daicel Chemical Industries, hexane/2-propanol $=96: 4,0.7$ $\mathrm{mL} / \mathrm{min}, 40{ }^{\circ} \mathrm{C}, 220 \mathrm{~nm} \mathrm{UV}$ detector, retention time $=39.6 \mathrm{~min}$ for $R$ isomer and $41.3 \mathrm{~min}$ for $S$ isomer]. The absolute configuration of 6ia was assigned by consideration of the stereochemical pathway.

4.4.26. 2-[\{(S)-7-Methyl-7-phenethyl-8-nonen-1yl\}oxy]tetrahydro-2H-pyran (6ja) (Diastereomeric ratio 1:1). The product $\mathbf{6 j a}$ was purified by flash chromatography on silica gel (0-2\% EtOAc/hexane) (70\% isolated yield). Colorless Oil. IR (neat) 1022, 1032, 1119, 2859, $2931 \mathrm{~cm}^{-1} .{ }^{1} \mathrm{H}$ NMR $(300 \mathrm{MHz}$, $\left.\mathrm{CDCl}_{3}\right) \delta 1.02(\mathrm{~s}, 3 \mathrm{H}), 1.23-1.36(\mathrm{~m}, 6 \mathrm{H}), 1.54-1.87(\mathrm{~m}, 12 \mathrm{H})$, 2.47-2.53 (m, 2H), $3.38(\mathrm{~m}, 1 \mathrm{H}), 3.51(\mathrm{~m}, 1 \mathrm{H}), 3.73(\mathrm{~m}, 1 \mathrm{H})$, $3.87(\mathrm{~m}, 1 \mathrm{H}), 4.58(\mathrm{~m}, 1 \mathrm{H}), 4.94(\mathrm{~d}, J=17.4 \mathrm{~Hz}, 1 \mathrm{H}), 5.03(\mathrm{~d}, J$ $=11.1 \mathrm{~Hz}, 1 \mathrm{H}), 5.75(\mathrm{dd}, J=17.4,11.1 \mathrm{~Hz}, 1 \mathrm{H}), 7.15-7.18(\mathrm{~m}$, $3 \mathrm{H}), 7.25-7.30(\mathrm{~m}, 2 \mathrm{H}) .{ }^{13} \mathrm{C}$ NMR $\left(100.5 \mathrm{MHz}, \mathrm{CDCl}_{3}\right) \delta$

$22.6,24.0,25.5,26.3,29.8,30.3,30.7,30.8,39.6,40.9,43.0$,
$62.4,67.7,98.8,111.8,125.5,128.3$ (2C), 143.4, 147.1. HRMS-

EI $(m / z):[\mathrm{M}]^{+}$calcd for $\mathrm{C}_{23} \mathrm{H}_{36} \mathrm{O}_{2}, 344.27153$; found, 344.27045 . $[\alpha]_{\mathrm{D}}{ }^{28}+5.94\left(c 0.87, \mathrm{CHCl}_{3}\right)$. The ee value $(86 \%$ ee $)$ was determined by chiral HPLC analysis of 7-(dimethoxymethyl)-7methyl-9-phenyl-1-nonanol obtained by the ozonolysis, reduction with $\mathrm{Me}_{2} \mathrm{~S}$ followed by acetalization $(\mathrm{MeOH}, p-\mathrm{TsOH}$, rt) from 6ja $\quad$ [CHIRALCEL $^{\circledR}$ OD-3 column, $4.6 \mathrm{~mm} \times 250$ $\mathrm{mm} / \mathrm{CHIRALCEL}^{\circledR} \quad$ OD-H column, $4.6 \mathrm{~mm} \times 250$ $\mathrm{mm} /$ CHIRALCEL $^{\circledR}$ OD-H column, $4.6 \mathrm{~mm} \times 250 \mathrm{~mm}$, Daicel Chemical Industries, hexane $/ 2$-propanol $=96: 4,0.7 \mathrm{~mL} / \mathrm{min}, 40$ ${ }^{\circ} \mathrm{C}, 220 \mathrm{~nm}$ UV detector, retention time $=39.6 \mathrm{~min}$ for $R$ isomer and $41.2 \mathrm{~min}$ for $S$ isomer]. The absolute configuration of $\mathbf{6 j a}$ was assigned by consideration of the stereochemical pathway.

4.4.27. (S)-[7-(Benzyloxy)-3-methyl-3-vinylheptyl]benzene (6ka). The product 6 ka was purified by flash chromatography on silica gel (0-2\% EtOAc/hexane) (68\% isolated yield). Colorless Oil. IR (neat) 696, 733, 1102, 1454, 2862, $2936 \mathrm{~cm}^{-1}$. ${ }^{1} \mathrm{H}$ NMR $\left(300 \mathrm{MHz}, \mathrm{CDCl}_{3}\right) \delta 1.03(\mathrm{~s}, 3 \mathrm{H}), 1.23-1.37(\mathrm{~m}, 4 \mathrm{H}), 1.52-1.64$ $(\mathrm{m}, 4 \mathrm{H}), 2.47-2.52(\mathrm{~m}, 2 \mathrm{H}), 3.46(\mathrm{t}, J=6.6 \mathrm{~Hz}, 2 \mathrm{H}), 4.50(\mathrm{~s}$, 2H), $4.94(\mathrm{~d}, J=17.4 \mathrm{~Hz}, 1 \mathrm{H}), 5.04(\mathrm{~d}, J=10.8 \mathrm{~Hz}, 1 \mathrm{H}), 5.75$ $(\mathrm{dd}, J=17.4,10.8 \mathrm{~Hz}, 1 \mathrm{H}), 7.14-7.18(\mathrm{~m}, 3 \mathrm{H}), 7.24-7.34(\mathrm{~m}$, 7H). ${ }^{13} \mathrm{C}$ NMR $\left(100.5 \mathrm{MHz}, \mathrm{CDCl}_{3}\right) \delta$

$39.6,40.7,42.9,70.3,72.9,111.9,125.5,127.5,127.7(2 \mathrm{C})$,
128.3 (2C), 138.6, 143.3, 147.0. HRMS-ESI $(\mathrm{m} / \mathrm{z}):[\mathrm{M}+\mathrm{Na}]^{+}$ calcd for $\mathrm{C}_{23} \mathrm{H}_{30} \mathrm{ONa}$, 345.21889; found, 345.21869. $[\alpha]_{\mathrm{D}}{ }^{22}+8.32$ (c $0.43, \mathrm{CHCl}_{3}$ ). HPLC analysis [CHIRALCEL ${ }^{\circledR}$ OD-3 column,
$4.6 \mathrm{~mm} \times 250 \mathrm{~mm}$, Daicel Chemical Industries, hexane/2propanol $=95: 5,0.5 \mathrm{~mL} / \mathrm{min}, 40{ }^{\circ} \mathrm{C}, 220 \mathrm{~nm}$ UV detector, retention time $=49.1 \mathrm{~min}$ for $R$ isomer and $51.7 \mathrm{~min}$ for $S$ isomer] revealed that the enantiomeric excess of $6 \mathbf{k a}$ was $81 \%$ ee. The absolute configuration of $6 \mathbf{k a}$ was assigned by consideration of the stereochemical pathway.

4.4.28. (S)-(3-Ethyl-3-methyl-4-penten-1-yl)benzene (6la). The product 6la was purified by flash chromatography on silica gel (hexane) followed by GPC $\left(\mathrm{CHCl}_{3}\right)(63 \%$ isolated yield $)$. Colorless Oil. IR (neat) 696, 752, 910, 1454, 2933, $2965 \mathrm{~cm}^{-1} .{ }^{1} \mathrm{H}$ NMR $\left(300 \mathrm{MHz}, \mathrm{CDCl}_{3}\right) \delta 0.82(\mathrm{t}, J=7.5 \mathrm{~Hz}, 3 \mathrm{H}), 1.01(\mathrm{~s}, 3 \mathrm{H})$, $1.39(\mathrm{q}, J=7.5 \mathrm{~Hz}, 2 \mathrm{H}), 1.51-1.61(\mathrm{~m}, 2 \mathrm{H}), 2.47-2.53(\mathrm{~m}, 2 \mathrm{H})$, $4.95(\mathrm{dd}, J=17.4,1.5 \mathrm{~Hz}, 1 \mathrm{H}), 5.05(\mathrm{dd}, J=10.8,1.5 \mathrm{~Hz}, 1 \mathrm{H})$, $5.74(\mathrm{dd}, J=17.4,10.8 \mathrm{~Hz}, 1 \mathrm{H}), 7.15-7.21(\mathrm{~m}, 3 \mathrm{H}), 7.25-7.29$ $(\mathrm{m}, 2 \mathrm{H}) .{ }^{13} \mathrm{C}$ NMR $\left(100.5 \mathrm{MHz}, \mathrm{CDCl}_{3}\right) \delta$

HRMS-EI $(\mathrm{m} / \mathrm{z}):[\mathrm{M}]^{+}$calcd for $\mathrm{C}_{14} \mathrm{H}_{20}, 188.15650$; found, 188.15651 . $[\alpha]_{\mathrm{D}}^{22}+16.69\left(c \quad 0.63, \mathrm{CHCl}_{3}\right)$ The ee value $(71 \%$ ee $)$ was determined by chiral HPLC analysis of 2-ethyl-2-methyl-4phenyl-1-butanol obtained by the ozonolysis followed by reduction with $\mathrm{NaBH}_{4}$ from 6la [CHIRALCEL ${ }^{\circledR}$ OD-3 column, $4.6 \mathrm{~mm} \times 250 \mathrm{~mm} / \mathrm{CHIRALCEL}^{\circledR}$ OD-H column, $4.6 \mathrm{~mm} \times 250$ $\mathrm{mm} / \mathrm{CHIRALCEL}^{\circledR}$ OD-H column, $4.6 \mathrm{~mm} \times 250 \mathrm{~mm}$, Daicel Chemical Industries, hexane $/ 2$-propanol $=96: 4,0.7 \mathrm{~mL} / \mathrm{min}, 40$ ${ }^{\circ} \mathrm{C}, 220 \mathrm{~nm}$ UV detector, retention time $=39.6 \mathrm{~min}$ for $R$ isomer and $44.5 \mathrm{~min}$ for $S$ isomer].

Derivatization of 6la (Scheme 4c). Ozone was bubbled into a solution of 6la $(7.4 \mathrm{mg}, 0.04 \mathrm{mmol})$ in $\mathrm{MeOH} /$ diethyl ether (1:10, $5.0 \mathrm{~mL})$ at $-78{ }^{\circ} \mathrm{C}$. After the starting material was completely disappeared (monitored by TLC), $\mathrm{NaBH}_{4}(15.1 \mathrm{mg}, 0.4 \mathrm{mmol})$ was added and the mixture was allowed to warm to room temperature and it was further stirred at the room temperature for $1 \mathrm{~h}$. The mixture was quenched with water. The aqueous layer was extracted with EtOAc (three times). The combined organic layer was washed with water and brine, and then was dried and concentrated. Purification by column chromatography (silica gel, 5-15\% EtOAc/hexane) yielded (S)-2-ethyl-2-methyl-4-phenyl-1butanol (6laa) $(3.8 \mathrm{mg}, 0.02 \mathrm{mmol}) .\left\{\mathrm{lit}^{24},(S)\right.$ isomer, $96 \%$ ee, $\left.[\alpha]_{\mathrm{D}}{ }^{20}-12.48\left(c 0.125, \mathrm{CH}_{2} \mathrm{Cl}_{2}\right)\right\}$.

4.4.29. (S)-4-(4,8-Dimethyl-4-vinyl-7-nonen-1-yl)-1,2dimethoxybenzene (6ab). The product $\mathbf{6 a b}$ was purified by flash chromatography on silica gel (0-2\% EtOAc/hexane) followed by GPC $\left(\mathrm{CHCl}_{3}\right)(54 \%$ isolated yield). Colorless Oil. IR (neat) 1031, $1235,1260,1515,2854,2933 \mathrm{~cm}^{-1} .{ }^{1} \mathrm{H}$ NMR $\left(300 \mathrm{MHz}, \mathrm{CDCl}_{3}\right)$ $\delta 0.95(\mathrm{~s}, 3 \mathrm{H}), 1.25-1.35(\mathrm{~m}, 4 \mathrm{H}), 1.46-1.61(\mathrm{~m}, 5 \mathrm{H}), 1.67(\mathrm{~s}$, $3 \mathrm{H}), 1.80-1.89(\mathrm{~m}, 2 \mathrm{H}), 2.51(\mathrm{t}, J=7.5 \mathrm{~Hz}, 2 \mathrm{H}), 3.86(\mathrm{~s}, 3 \mathrm{H})$, $3.88(\mathrm{~s}, 3 \mathrm{H}), 4.87(\mathrm{dd}, J=17.4,1.5 \mathrm{~Hz}, 1 \mathrm{H}), 4.97(\mathrm{dd}, J=10.8$, $1.5 \mathrm{~Hz}, 1 \mathrm{H}), 5.08(\mathrm{~m}, 1 \mathrm{H}), 5.68(\mathrm{dd}, J=17.4,10.8 \mathrm{~Hz}, 1 \mathrm{H})$, 6.69-6.72 (m, 2H), $6.79(\mathrm{~m}, 1 \mathrm{H}) .{ }^{13} \mathrm{C} \mathrm{NMR}\left(100.5 \mathrm{MHz}, \mathrm{CDCl}_{3}\right)$ $\delta 17.6,22.5,22.8,25.7,26.3,36.3,39.4,40.4,40.7,55.8 .55 .9$
$111.1,111.5,111.7,120.1,125.0,131.0,135.4,147.0,147.2$ HRMS-EI $(\mathrm{m} / \mathrm{z}):[\mathrm{M}]^{+}$calcd for $\mathrm{C}_{21} \mathrm{H}_{32} \mathrm{O}_{2}, 316.24023$; found, 316.24053. $[\alpha]_{\mathrm{D}}{ }^{23}+8.40\left(c \quad 0.50, \mathrm{CHCl}_{3}\right)$. The ee value (73\% ee) was determined by chiral HPLC analysis of 2-[3-(3,4dimethoxyphenyl)propyl]-2-methyl-6-oxabicyclo[3.1.0]hexane obtained by the ring closing metathesis (Grubbs $2^{\text {nd }}$ catalyst, $\mathrm{DCM}, 40{ }^{\circ} \mathrm{C}$ ) followed by epoxydation ( $\mathrm{mCPBA}, \mathrm{NaHCO}_{3}$, DCM, $0{ }^{\circ} \mathrm{C}$ ) from 6ab [CHIRALCEL ${ }^{\circledR}$ OD-3 column, $4.6 \mathrm{~mm} \times$ $250 \mathrm{~mm}$, Daicel Chemical Industries, hexane/2-propanol = 99:1, $0.5 \mathrm{~mL} / \mathrm{min}, 40{ }^{\circ} \mathrm{C}, 220 \mathrm{~nm} \mathrm{UV}$ detector, retention time $=46.0$ min and $65.7 \mathrm{~min}$ for $R$ isomer and $48.2 \mathrm{~min}$ and $85.3 \mathrm{~min}$ for $S$ isomer]. The absolute configuration of $\mathbf{6 a b}$ was assigned by consideration of the stereochemical pathway. 
4.4.30. (S)-2-(6-Ethyl-6-phenethyl-7-octen-1-yl)-1,3-dioxane (6cc). The product $6 \mathbf{c c}$ was purified by flash chromatography on silica gel (0-2\% EtOAc/hexane) followed by GPC $\left(\mathrm{CHCl}_{3}\right)(75 \%$ isolated yield). Colorless Oil. IR (neat) 698, 909, 998, 1143, 2851, $2929 \mathrm{~cm}^{-1} .{ }^{1} \mathrm{H}$ NMR $\left(300 \mathrm{MHz}, \mathrm{CDCl}_{3}\right) \delta 0.79(\mathrm{t}, J=7.2 \mathrm{~Hz}$, $3 \mathrm{H}), 1.20-1.45(\mathrm{~m}, 10 \mathrm{H}), 1.53-1.63(\mathrm{~m}, 5 \mathrm{H}), 2.08(\mathrm{~m}, 1 \mathrm{H}), 2.41-$ $2.47(\mathrm{~m}, 2 \mathrm{H}), 3.76(\mathrm{td}, J=12.0,2.4 \mathrm{~Hz}, 2 \mathrm{H}), 4.08-4.13(\mathrm{~m}, 2 \mathrm{H})$, 4.51 (t, $J=5.1 \mathrm{~Hz}, 1 \mathrm{H}), 4.91$ (dd, $J=17.4,1.5 \mathrm{~Hz}, 1 \mathrm{H}), 5.08$ (dd, $J=11.1,1.5 \mathrm{~Hz}, 1 \mathrm{H}), 5.64(\mathrm{dd}, J=17.4,11.1 \mathrm{~Hz}, 1 \mathrm{H}), 7.15-7.19$ $(\mathrm{m}, 3 \mathrm{H}), 7.25-7.30(\mathrm{~m}, 2 \mathrm{H}) .{ }^{13} \mathrm{C}$ NMR $\left(100.5 \mathrm{MHz}, \mathrm{CDCl}_{3}\right) \delta$ $7.8,23.3,24.0,25.9,28.4,30.1,30.4,35.3,35.6,38.3,42.1,66.9$, HRMS-EI $(\mathrm{m} / \mathrm{z})$ : $[\mathrm{M}]^{+}$calcd for $\mathrm{C}_{22} \mathrm{H}_{34} \mathrm{O}_{2}, 330.25588$; found, 330.25466. $[\alpha]_{\mathrm{D}}^{26}-$ $5.63\left(c 0.48, \mathrm{CHCl}_{3}\right)$. The ee value $(81 \%$ ee) was determined by chiral HPLC analysis of the aldehyde derivative obtained by the ozonolysis followed by reduction with $\mathrm{Me}_{2} \mathrm{~S}$ from 6cc [CHIRALCEL $^{\circledR}$ OD-3 column, $4.6 \mathrm{~mm} \times 250$ mm/CHIRALCEL ${ }^{\circledR} \quad$ OD-H column, $4.6 \mathrm{~mm} \times 250$ $\mathrm{mm} / \mathrm{CHIRALCEL}^{\circledR}$ OD-H column, $4.6 \mathrm{~mm} \times 250 \mathrm{~mm}$, Daicel Chemical Industries, hexane/2-propanol $=96: 4,0.7 \mathrm{~mL} / \mathrm{min}, 40$ ${ }^{\circ} \mathrm{C}, 220 \mathrm{~nm}$ UV detector, retention time $=37.4 \mathrm{~min}$ for $S$ isomer and $42.5 \mathrm{~min}$ for $R$ isomer]. The absolute configuration of $\mathbf{6 c c}$ was assigned by consideration of the stereochemical pathway.

4.4.31. (S)-2-(6-Phenethyl-6-vinylnonyl)-1,3-dioxane (6cd). The product $\mathbf{6 c d}$ was purified by flash chromatography on silica gel $\left(0-2 \%\right.$ EtOAc/hexane) followed by $\mathrm{GPC}\left(\mathrm{CHCl}_{3}\right) \quad(67 \%$ isolated yield). Colorless Oil. IR (neat) 698, 908, 998, 1144, 2850, $2929 \mathrm{~cm}^{-1} .{ }^{1} \mathrm{H}$ NMR $\left(300 \mathrm{MHz}, \mathrm{CDCl}_{3}\right) \delta 0.89(\mathrm{t}, J=6.9 \mathrm{~Hz}$, $3 \mathrm{H}), 1.19-1.47$ (m, 12H), 1.53-1.62 (m, 5H), $2.04(\mathrm{~m}, 1 \mathrm{H}), 2.41-$ $2.47(\mathrm{~m}, 2 \mathrm{H}), 3.76(\mathrm{t}, J=12.0 \mathrm{~Hz}, 2 \mathrm{H}), 4.08-4.13(\mathrm{~m}, 2 \mathrm{H}), 4.51$ $(\mathrm{t}, J=5.1 \mathrm{~Hz}, 1 \mathrm{H}), 4.90(\mathrm{~d}, J=17.4 \mathrm{~Hz}, 1 \mathrm{H}), 5.06(\mathrm{~d}, J=11.1$ $\mathrm{Hz}, 1 \mathrm{H}), 5.65$ (dd, $J=17.4,11.1 \mathrm{~Hz}, 1 \mathrm{H}), 7.14-7.18(\mathrm{~m}, 3 \mathrm{H})$, 7.24-7.29 (m, 2H). $\left.{ }^{13} \mathrm{C} \mathrm{NMR} \mathrm{(100.5} \mathrm{MHz,} \mathrm{CDCl}_{3}\right) \delta$

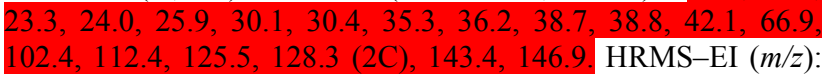
$[\mathrm{M}]^{+}$calcd for $\mathrm{C}_{23} \mathrm{H}_{36} \mathrm{O}_{2}, 344.27153$; found, 344.27039. $[\alpha]_{\mathrm{D}}^{22}-$ 3.06 ( $\left.c 0.23, \mathrm{CHCl}_{3}\right)$. The ee value $(71 \%$ ee) was determined by chiral HPLC analysis of the aldehyde derivative obtained by the ozonolysis followed by reduction with $\mathrm{Me}_{2} \mathrm{~S}$ from 6cd [CHIRALCEL ${ }^{\circledR}$ OD-3 column, $4.6 \mathrm{~mm} \times 250$ mm/CHIRALCEL ${ }^{\circledR} \quad$ OD-H column, $4.6 \mathrm{~mm} \times 250$ $\mathrm{mm} /$ CHIRALCEL $^{\circledR}$ OD-H column, $4.6 \mathrm{~mm} \times 250 \mathrm{~mm}$, Daicel Chemical Industries, hexane/2-propanol $=96: 4,0.7 \mathrm{~mL} / \mathrm{min}, 40$ ${ }^{\circ} \mathrm{C}, 220 \mathrm{~nm}$ UV detector, retention time $=29.9 \mathrm{~min}$ for $S$ isomer and $32.6 \mathrm{~min}$ for $R$ isomer]. The absolute configuration of $\mathbf{6 c d}$ was assigned by consideration of the stereochemical pathway.

\section{Acknowledgments}

This work was supported by Grants-in-Aid for Young Scientists (A) and Challenging Exploratory Research, JSPS to H.O. and by ACT-C, JST to M.S. and S.M. and by CREST, JST to M.S. K.N. thanks JSPS for scholarship support.

\section{References and notes}

1. For reviews on $\mathrm{Cu}$-catalyzed enantioselective allylic substitutions with organomagnesium, organozinc or organoaluminum reagents, see: (a) Hoveyda, A. H.; Hird, A. W.; Kacprzynski, M. A. Chem. Commun. 2004, 1779-1785. (b) Yorimitsu, H.; Oshima, K. Angew. Chem. Int. Ed. 2005, 44, 4435-4439. (c) Falciola, C. A.; Alexakis, A. Eur. J. Org. Chem. 2008, 3765-3780. (d) Alexakis, A.; Bäckvall, J. E.; Krause, N.; Pàmies, O.; Diéguez, M. Chem. Rev. 2008, 108, 2796-2823. (e) Harutyunyan, S. R.; den Hartog, T.; Geurts, K.; Minnaard, A. J.; Feringa, B. L. Chem. Rev. 2008, 108, 2824-2852. For a Cu-catalyzed allylic substitution with alkyllithium reagents, see: (f) Fañanás-Mastral, M.; Pérez, M.;
Bos, P. H.; Rudolph, A.; Harutyunyan, S. R.; Feringa, B. L. Angew. Chem. Int. Ed. 2012, 51, 1922-1925.

2. For a review on transition-metal-catalyzed allylic substitutions with organoboron compounds, see: Pigge, F. C. Synthesis 2010, 1745-1762.

3. For Ni-catalyzed enantioselective allylic substitution of arylboronic acids, see: Chung, K.-G.; Miyake, Y.; Uemura, S. J. Chem. Soc. Perkin Trans. 1 2000, 15-18.

4. For Cu-catalyzed enantioselective allylic substitutions with aryl-, alkenyl- and allenylboronates, see: (a) Shintani, R.; Takatsu, K.; Takeda, M.; Hayashi, T. Angew. Chem. Int. Ed. 2011, 50, 86568659. (b) Jung, B.; Hoveyda, A. H. J. Am. Chem. Soc. 2012, 134 1490-1493. (c) Gao, F.; Carr, J. L.; Hoveyda, A. H. Angew. Chem. Int. Ed. 2012, 51, 6613-6617.

5. For Pd-catalyzed enantioselective allylic substitutions with allylboronates, see: (a) Zhang, P.; Brozek, L. A.; Morken, J. P. J. Am. Chem. Soc. 2010, 132, 10686-10688. (b) Zhang, P.; Le, H.; Kyne, R. E.; Morken, J. P. J. Am. Chem. Soc. 2011, 133, 97169719. (c) Brozek, L. A.; Ardolino, M. J.; Morken, J. P. J. Am. Chem. Soc. 2011, 133, 16778-16781.

6. For Rh-catalyzed enantioselective allylic substitution of cis-4cyclopenten-1,3-diol derivatives with arylboronic acids, see: (a) Menard, F.; Chapman, T. M.; Dockendorff, C.; Lautens, M. Org. Lett. 2006, 8, 4569-4572. (b) Menard, F.; Perez, D.; Roman, D. S.; Chapman, T. M.; Lautens, M. J. Org. Chem. 2010, 75, 40564068. For Rh-catalyzed enantioselective allylic substitution of (Z)2-butene-1,4-diol derivatives with arylboron compounds, see: (c) Miura, T.; Takahashi, Y.; Murakami, M. Chem. Commun. 2007, 595-597. (d) Yu, B.; Menard, F.; Isono, N.; Lautens, M. Synthesis 2009, 853-859. For Rh-catalyzed enantioselective allylic substitution of allylic ethers with arylboronic acids, see: (e) Kiuchi, H.; Takahashi, D.; Funaki, K.; Sato, T.; Oi, S. Org. Lett. 2012, 14, 4502-4505.

7. (a) Shido, Y.; Yoshida, M.; Tanabe, M.; Ohmiya, H.; Sawamura, M. J. Am. Chem. Soc. 2012, 134, 18573. (b) Hojoh, K.; Shido, Y.; Ohmiya, H.; Sawamura, M. Angew. Chem. Int. Ed. 2014, 53, 4954.

8. For $\mathrm{Cu}$-catalyzed $\gamma$-selective allylic substitutions with alkyl-9BBN (non-enantioselective system), see: (a) Ohmiya, H.; Yokobori, U.; Makida, Y.; Sawamura, M. J. Am. Chem. Soc. 2010, 132, 2895-2897. (b) Nagao, K.; Ohmiya, H.; Sawamura, M. Synthesis 2012, 44, 1535-1541. (c) Nagao, K.; Yokobori, U.; Makida, Y.; Ohmiya, H.; Sawamura, M. J. Am. Chem. Soc. 2012, 134, 8982-8987. (d) Whittaker, A. M.; Rucker, R. P.; Lalic, G. Org. Lett. 2010, 12, 3216-3218. See also: (e) Ohmiya, H.; Yokobori, U.; Makida, Y.; Sawamura, M. Org. Lett. 2011, 13, 6312-6315.

9. For $\mathrm{Cu}$-catalyzed enantioselective conjugate addition with alkyl-9BBN reagents, see: (a) Yoshida, M.; Ohmiya, H.; Sawamura, M. J. Am. Chem. Soc. 2012, 134, 11896-11899. See also: (b) Ohmiya, H.; Yoshida, M.; Sawamura, M. Org. Lett. 2011, 13, 482-485. (c) Ohmiya, H.; Shido, Y.; Yoshida, M.; Sawamura, M. Chem. Lett. 2011, 40, 928-930.

10. For Tables 1-4 and Scheme 2, unreacted allyl chloride (3) was detected in the crude materials after removal of the catalyst.

11. Herrmann, W. A.; Goossen, L. J.; Köcher, C.; Artus, G. R. J. Angew. Chem. Int. Ed. 1996, 35, 2805-2807.

12. Saito, T.; Yokozawa, T.; Ishizaki, T.; Moroi, T.; Sayo, N.; Miura, T.; Kumobayashi, H. Adv. Synth. Catal. 2001, 343, 264-267.

13. Imamoto, T.; Sugita, K.; Yoshida, K. J. Am. Chem. Soc. 2005, 127, 11934-11935.

14. For discussion on the effect of the DTBM groups in the enantioselective copper-catalyzed hydrosilylation of aryl ketones, see: Lipshutz, B. H.; Noson, K.; Chrisman, W.; Lower, A. J. Am. Chem. Soc. 2003, 125, 8779-8789.

15. For stereoconvergent synthesis of $\alpha$-stereogenic chiral allylboronates from an $E / Z$ mixture of allylic aryl ethers using a NHC-Cu catalyst, see: Park, J. K.; Lackey, H. H.; Ondrusek, B. A.; McQuade, D. T. J. Am. Chem. Soc. 2011, 133, 2410-2413.

16. For reviews on the synthesis of allylsilanes, see: (a) Masse, C. E.; Panek, J. S. Chem. Rev. 1995, 95, 1293-1316. (b) Fleming, I.; Barbero, A.; Walter, D. Chem. Rev. 1997, 97, 2063-2192. (c) Chabaund, L.; James, P.; Landais, Y. Eur. J. Org. Chem. 2004, 3173-3199.

17. For the synthesis of enantioenriched allylsilanes through $\mathrm{Cu}$ catalyzed enantioselective allylic substitutions of prochiral $\gamma$ silylated primary allylic alcohol derivatives with organozinc or organoaluminum reagents, see: (a) Kacprzynski, M. A.; May, T. L.; Kazane, S. A.; Hoveyda, A. H. Angew. Chem. Int. Ed. 2007, 
46, 4554-4558. (b) Gao, F.; McGrath, K. P.; Lee, Y.; Hoveyda, A. H. J. Am. Chem. Soc. 2010, 132, 14315-14320. For the synthesis of allylsilanes through copper-catalyzed allylic substitutions with silylating reagents, see: (c) Vyas, D. J.; Oestreich, M. Chem. Commun. 2010, 568-570. (d) Vyas, D. J.; Oestreich, M. Angew. Chem. Int. Ed. 2010, 49, 8513-8515.

18. For the synthesis of enantioenriched allylsilanes through palladium-catalyzed allylic substitutions of enantioenriched $\gamma$ silylated secondary allylic alcohol derivatives with organoboronic acids, see: Li, D.; Tanaka, T.; Ohmiya, H.; Sawamura, M. Org. Lett. 2010, 12, 3344-3347.

19. (a) Das, J. P.; Marek, I. Chem. Commun. 2011, 47, 4593-4623. (b) Marek, I.; Minko, Y.; Pasco, M.; Mejuch, T.; Gilboa, N.; Chechik, H.; Das, J. P. J. Am. Chem. Soc. 2014, 136, 2682-2694.

20. For Tables 5-7 and Scheme 3, small amounts of dechlorinated compounds that stemmed solely from the allyl chloride (5) were detected in the crude materials after removal of the catalyst.

21. Sun, X.; Zhou, L.; Li, W.; Zhang, X. J. Org. Chem. 2008, 73, $1143-1146$.

22. Västilä, P.; Pastor, I. M. B.; Andolfsson, H. J. Org. Chem. 2005, 70, 2921-2929.

23. (a) Fleming, I.; Henning, R.; Plaut, H. J. Chem. Soc., Chem. Commun. 1984, 29-31. (b) Jones, G. R.; Landais, Y. Tetrahedron 1996, 52, 7599-7662.

24. Simaan, S.; Goldberg, A. F. G.; Rosset, S.; Marek, I. Chem. Eur. J. 2010, 16, 774-778.

25. Details of the DFT calculations will be reported elsewhere.

26. (a) Yoshikai, N.; Zhang, S.-L.; Nakamura, E. J. Am. Chem. Soc. 2008, 130, 12862-12863. (b) Yamanaka, M.; Kato, S.; Nakamura,
E. J. Am. Chem. Soc. 2004, 126, 6287-6293. For a review, see: (c) Yoshikai, N.; Nakamura, E. Chem. Rev. 2012, 112, 2339-2372.

27. Liu and co-workers proposed an $\mathrm{S}_{\mathrm{N}} 2$-type substitution of arylcuprate species with primary alkyl (pseudo)halides in the $\mathrm{Cu}$ catalyzed cross-coupling reaction with arylboronate reagents. See: Yang, C.-T.; Zhang, Z.-Q.; Liu, Y.-C.; Liu, L. Angew. Chem. Int. Ed. 2011, 50, 3904-3907.

28. (a) Magid, R. M.; Fruchey, O. S.; Johnson, W. L. Tetrahedron Lett. 1977, 18, 2999-3002. (b) Katcher, M. H.; Sha, A.; Doyle, A. G. J. Am. Chem. Soc. 2011, 133, 15902-15905. (c) Kelly, B. D.; Lambert, T. H. J. Am. Chem. Soc. 2009, 131, 13930-13931.

\section{Supplementary Material}

Supplementary material that may be helpful in the review process should be prepared and provided as a separate electronic file. That file can then be transformed into PDF format and submitted along with the manuscript and graphic files to the appropriate editorial office. 


\section{Graphical Abstract}

To create your abstract, type over the instructions in the template box below.

Fonts or abstract dimensions should not be changed or altered.

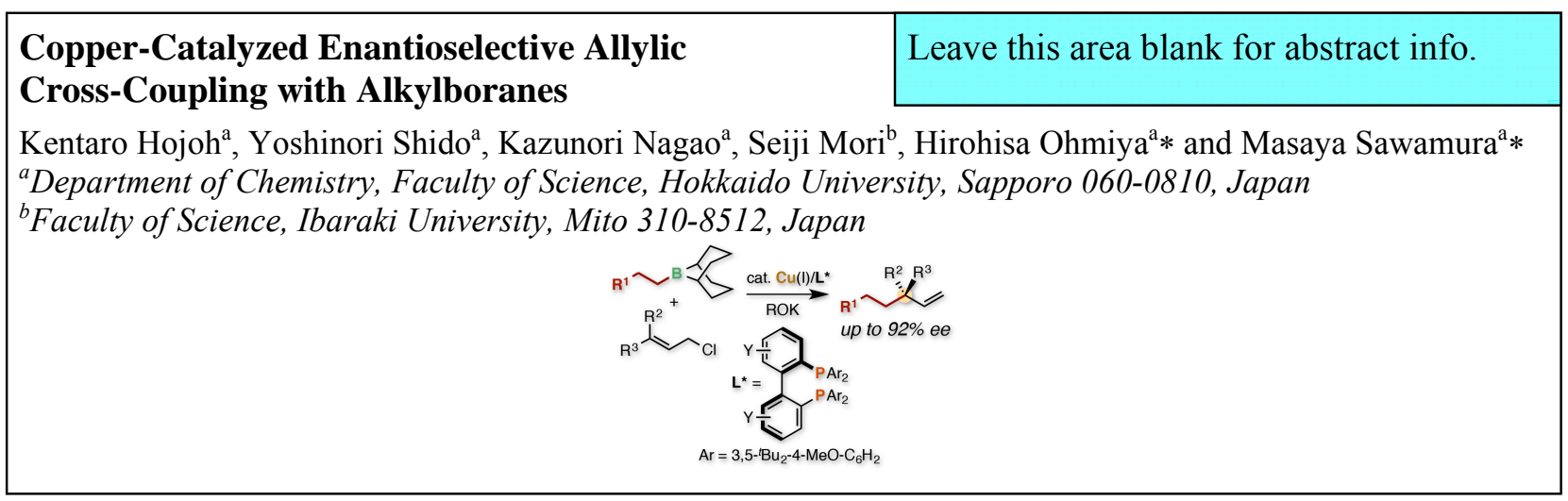

